\title{
PROVOCATIVE CLIMATE PROTECTION: EU 'EXTRATERRITORIAL' REGULATION OF MARITIME EMISSIONS
}

\author{
Natalie L. Dobson and Cedric Ryngaert*
}

\begin{abstract}
In 2015, frustrated by the slow pace of negotiations in the International Maritime Organisation, the EU issued Regulation 2015/757 on the monitoring, reporting, and verification of carbon dioxide emissions from maritime transport. Echoing the controversial Aviation Directive, the Regulation is intended to support a unilateral market-based measure, and includes emissions from outside EU territory. This raises the question whether, according to international law, the EU has jurisdiction to regulate such 'extraterritorial' circumstances. In exploring the appropriate jurisdictional bases, we argue that neither the Law of the Sea Convention, nor world trade law definitively decide this issue. We therefore devote more detailed attention to the customary international law of State jurisdiction supplementing these regimes. We seek to build on the existing analysis by examining climate change as a 'common concern of mankind'. We argue that this emerging concept has distinct legal implications that can and should be accommodated within the interestbalancing exercise underlying the jurisdictional analysis.
\end{abstract}

Keywords: climate change, common concern, EU, extraterritoriality, jurisdiction, Law of the Sea, maritime, world trade law.

\section{INTRODUCTION}

With the conclusion of the Paris Agreement in December 2015, the international community reinforced its resolve to mitigate the devastating effects of global warming on ecosystems and human welfare. ${ }^{1}$ The Paris Agreement represents the first globally inclusive instrument to tackle climate change as a 'common concern of mankind'. ${ }^{2}$ However, despite the

* The authors are, respectively, PhD Fellow at the Faculty of Law, Economics and Governance, Utrecht University, N.L.Dobson@uu.nl, and Professor of Public International Law, Utrecht University, C.M.J.Ryngaert@uu.nl. The research which resulted in this publication has been funded by the European Research Council under the Starting Grant Scheme (Proposal 336230 UNIJURIS) and the Dutch Organization for Scientific Research under the VIDI Scheme (No 016.135.322).

${ }^{1}$ UNFCCC, Draft Decision -/CP.21 'Paris Agreement' (2015) 7 FCCC/CP/2015/L.9/Rev.1 (Paris Agreement).

\footnotetext{
2 Paris Agreement rec 7.
} 
political success, there remains a considerable 'ambition gap' between countries' voluntary pledges and the emission reductions required to prevent a dangerous rise in the global temperature. ${ }^{3}$ In particular, the Paris Agreement is silent on maritime emissions, which remain excluded from States' mandatory commitments under the Kyoto Protocol. ${ }^{4}$ The 1997 Kyoto Protocol encourages Annex I parties to seek a multilateral solution 'working through' the International Maritime Organisation (IMO). ${ }^{5}$ However, almost two decades later, the IMO is yet to agree on a binding global instrument for the reduction of $\mathrm{CO}_{2}$ emissions.

Impatient with the slow international negotiations, the EU has repeatedly threatened unilateral action, though to little avail. ${ }^{6}$ Finally, in 2015 the Union went ahead and adopted Regulation 2015/757 (the Regulation) setting out a monitoring, reporting, and verification (MRV) scheme for maritime emissions as the first step towards a market-based measure (MBM) incorporating these emissions into the EU's independent reduction commitment. ${ }^{7}$ MBMs use economic policy tools to influence the decisions of private operators, particularly through harmonizing the dual incentives of profit-making and pollution reduction. ${ }^{8}$ The maritime MRV serves as a prerequisite for such an MBM, providing the data necessary to determine operators' emission reduction targets. ${ }^{9}$ Importantly, the scope of the Regulation includes the complete duration of voyages to and from EU ports, meaning that operators will be required to monitor and report $\mathrm{CO}_{2}$ emitted outside EU territory. Should the chosen MBM maintain the same scope, then these 'foreign' emissions will likely entail further costs for operators.

3 Paris Agreement (n 1) rec 10.

4 Kyoto Protocol to the United Nations Framework Convention on Climate Change (adopted 11 December 1997, entered into force 16 February 2005) UN Doc FCCC/CP/1997/7/Add. 1 (Kyoto Protocol, art 2(2). Reference to aviation and maritime emissions was dropped late in negotiations. See, 'Shipping Dropped from Paris Climate Deal' World Maritime News (10 December 2015) $<$ http://worldmaritimenews.com/archives/178438/shipping-dropped-from-paris-climate-deal/>.

5 ibid art 2(2).

6 See Parliament and Council Decision (EC) 1600/2002 laying down the Sixth Community Environment Action Programme [2002] OJ L 242/1. Art 5 (iii) provides for the Community to 'identify and undertake specific actions to reduce greenhouse gas emissions from aviation and maritime if no such action were agreed within the ICAO by 2002, the IMO by 2003'. Combatting climate change was incorporated as a formal Union objective in art 191(1) of the Consolidated Version of the Treaty on the Functioning of the European Union [2012] OJ C 326/ 47-390 (TFEU).

7 Parliament and Council (EU) Reg 2015/757 on the monitoring, reporting and verification of carbon dioxide emissions from maritime transport, and amending Directive 2009/16/EC [2015] OJ L 123/55 (Reg 2015/757). Note, the EU as a regional organization is considered here to exercise 'collective' unilateralism. See P Dupuy, 'The Place and Role of Unilateralism in Contemporary International Law’ (2000) 11 EJIL 19, 29.

${ }^{8}$ Commission (EU), 'Integrating maritime transport emissions in the EU's greenhouse gas reduction policies' (Communication) COM (2013/479) final, 28 June 2013 (COM (2013)479) 7.

9 ibid 7-8. 
There have already been considerable political objections from the shipping industry to the EU's decision to go it alone. ${ }^{10}$ In anticipation of increasing scrutiny in the run-up to implementation, this article explores the legal issues surrounding the EU's competence to unilaterally prescribe such measures. ${ }^{11}$ This issue is not uncontroversial; the negative international reaction to a similar EU measure in relation to aviation emissions led it to pause implementation pending negotiations within the International Civil Aviation Organisation (ICAO). ${ }^{12}$ However, the EU has not appeared poised to back down on either aviation or maritime emissions should multilateral negotiations fail to meet its standards. ${ }^{13}$ This raises the question whether, according to international law, the EU has jurisdiction to legislate Regulation 2015/757 and a further MBM with the same geographical scope. As the EU is yet to decide on a MBM, it is valuable to consider how the applicable rules of international law may affect the appropriate design of the projected measure. Importantly, as an international organization, the EU remains subject to

${ }^{10}$ See eg International Chamber of Shipping, 'Brief for EU Member States and Members of the European Parliament Proposal for a Regulation of The European Parliament and of the Council on the monitoring, reporting and verification of carbon dioxide emissions from maritime transport and amending Regulation (EU) No 525/2013 - Preliminary ICS Comments on Draft EU Regulation on MRV' (ics-shipping.org, 10 October 2013) <http://www.ics-shipping.org >. For further reported statements from International Chamber of Shipping, Bimco and Intercargo: Charalie Bartlett, 'Industry Groups "Disappointed but Not Surprised" at EU MRV Verdict' Seatrade Maritime News (London, 29 April 2015) <http://www.seatrade-maritime.com/news/europe/industrygroups-disappointed-but-not-surprised-at-eu-mrv-verdict.html>.

${ }_{11}$ It is generally accepted that art 2(2) Kyoto Protocol does not endow the IMO with exclusive competence to regulate maritime emissions. See eg T Bäuerle, 'Integrating Shipping into the EU Emissions Trading Scheme?' in H Koch, D König and J Sanden (eds), Climate change and environmental hazards related to shipping: an international legal framework; proceedings of the Hamburg International Environmental Law Conference 2011 (Martinus Nijhoff 2013); H Ringbom, 'Global Problem-Regional Solution? International Law Reflections on an $\mathrm{EU} \mathrm{CO}_{2} \mathrm{Emissions}$ Trading Scheme for Ships' (2011) 26 IJMCL 613. The unilateral nature of an act does not render it illegal, as legality is dependent on the legal framework in which it is taken. See for further discussion eg J Hartmann, 'Unilateralism in International Law: Implications of the Inclusion of Emissions from Aviation in the EU ETS' (2015) 11 Questions of International Law, Zoom In 19; M Hakimi, 'Unfriendly Unilateralism' (2014) 55 HarvInt'lLJ 105.

12 See Parliament and Council (EC) Directive 2008/101 amending Directive 2003/87/EC so as to include aviation activities in the scheme for greenhouse gas emission allowance trading within the Community [2008] OJ L 8/3 (Aviation Directive). This was followed by Parliament and Council (EU) Decision 377/2013 derogating temporarily from Directive 2003/87/EC establishing a scheme for greenhouse gas emission allowance trading within the Community [2013] OJ 113/1. Parliament and Council Regulation (EU) 421/2014 establishing a scheme for greenhouse gas emission allowance trading within the Community, in view of the implementation by 2020 of an international agreement applying a single global market-based measure to international aviation emissions [2014] OJ L 129/1-4, regulates the interim period.

${ }_{13}$ In late September 2016, pursuant to EU pressure, ICAO Member States reached the first global agreement targeting aviation emissions through 'carbon neutral' growth (ICAO 39th Session, Montreal). It remains to be seen whether this will be sufficient to prevent the EU from reinstating the full scope of the Aviation Directive. See R Marowitz, 'ICAO Begins Discussions Aimed at Reaching Global Aviation Emissions Deal' (CBC News, 27 September 2016) <http:// www.cbc.ca/news/canada/montreal/montreal-icao-aviation-39-general-assembly-1.3780375>. 
international law, including the law of State jurisdiction that applies to the competences conferred upon it by its Member States. ${ }^{14}$

Three legal sources are of particular relevance here: the UN Convention on the Law of the Sea (LOSC), ${ }^{15}$ the law of the World Trade Organization (WTO) and the customary international law of jurisdiction. The LOSC conditions the MRV's regulation of international shipping and port State measures against foreignflagged vessels, including its regulation of activities taking place beyond the EU's territory and maritime zones. The WTO is relevant insofar as the EU measures may unlawfully restrict international trade. Both of these regimes have been explored by scholars and research institutions, with differing results. ${ }^{16}$ Part of the divergence arises from the conflicting conceptions of 'extraterritoriality' that underlie the different analyses. This is ultimately a question of the customary law of State jurisdiction, which governs the geographical scope of the regulatory power of States and regional organizations.

This last regime deserves further attention, not least because of its important complementary role in relation to the two more specific fields. Indeed, the LOSC has been described as a 'clarification' and 'manifestation' of the customary international law of the sea, including the law of jurisdiction. ${ }^{17}$ The WTO Appellate Body (AB) has also held that WTO law 'should not be read in clinical isolation from public international law'. ${ }^{18}$ The latter finding is of particular relevance for the question of whether there is an implicit

${ }^{14}$ The Court of Justice of the EU (CJEU) has repeatedly confirmed that the EU is bound by international law, including the law of jurisdiction. See Case C-162/96 Racke v Hauptzollamt Mainz [1998] ECR I-3655 [45]; and Case C-366/10 Air Transport Association of America, American Airlines, Inc, Continental Airlines, Inc, United Airlines, Inc v The Secretary of State for Energy and Climate Change (ATAA Case) [2011] ECR I-0000 [123].

15 United Nations Convention on the Law of the Sea (adopted 10 December 1982, entered into force 16 November 1994) 1833 UNTS 3 (LOSC).

${ }^{16}$ For positive conclusions see, Bäuerle (n 11); Ringbom (n 11); T Bäuerle et al., 'Integration of Marine Transport into the European Emissions Trading System - Environmental, Economic and Legal Analysis of Different Options' (German Federal Environment Agency (Umweltbundesamt) 2010) Rep No (UBA-FB) 001372; H Murphy, 'The Extension of the EU ETS to Aviation and Shipping: Examining the Legality of Unilateral Environmental Measures under Public International Law and World Trade Organisation Law' < https://www.academia.edu/12831400>. For more critical conclusions, see C Hermeling et al., 'Sailing Into a Dilemma - An Economic and Legal Analysis of an EU Trading Scheme for Maritime Emissions' (Centre for European Economic Research 2014) Discussion Paper No 14-021; M Kremlis, "The Inclusion of the Shipping Industry in the EU ETS' (2010) 19 EEELR 145; J Faber et al., 'Technical Support for European Action to Reducing Greenhouse Gas Emissions from International Maritime Transport' (CE Delft 2009) Tender DG ENV.C3/ATA/2008/0016; A Miola et al., 'Regulating Air Emissions from Ships - The State of the Art on Methodologies, Technologies and Policy Options' (European Commission, Joint Research Centre, Institute for Environment and Sustainability 2010) JRC60732; P Campling et al., 'Market-Based Instruments for Reducing Air Pollution - Assessment of Policy Options to Reduce Air Pollution from Shipping' (Final Report for the European Commission's DG Environment, 2010) Contract ENV.C.4/SER/2008/0019_Lot2.

17 Ringbom (n 11) 629, 637.

18 WTO, United States - Standards for Reformulated and Conventional Gasoline - Panel Report (29 April 1996) WT/DS2/R (US-Gasoline (Panel) 17. For further discussion on the interaction between these regimes see J Pauwelyn, Conflict of Norms in Public International Law: How WTO Law Relates to Other Rules of International Law (CUP 2003). 
jurisdictional limitation in the general exemptions of Article XX of the General Agreement on Tariffs and Trade (GATT). ${ }^{19}$ The customary law of jurisdiction's complementary role is essential here because, as will be argued, while the trade and maritime regimes do contain rules on State regulatory competence in their respective fields, they do not definitively answer the question of whether the EU has jurisdiction to regulate maritime emissions outside of its territory.

On a more doctrinal level, a focus on customary law is further merited because it is this regime that is primarily designed to target the fundamental regulatory issue at stake here, namely how far a State or regional organization may go when unilaterally protecting a shared interest. We seek to build on the existing discussion by looking in more detail at climate change as a particular type of shared interest, namely a 'common concern of mankind'. We argue that this emerging concept has a distinct definition and legal implications, and that when States act to protect a common concern this affects the interest-balancing exercise underlying the jurisdictional analysis. ${ }^{20}$

Section II explores the nature of climate change as a 'common concern of mankind' and analyses its legal implications for the obligations of States and regional organizations such as the EU. It then examines the controversial issue of 'extraterritoriality' in international law, a matter which often arises when States take action to respond to common concerns. Section III turns its focus to Regulation 2015/757, analysing the relevant 'extraterritorial elements' that trigger the need for jurisdictional justification. Drawing from the discussion in the literature, Section IV considers to what extent a basis can be found in the LOSC and WTO law, in particular the GATT, for the EU's competence to legislate the MRV and the projected MBMs. It concludes that, in principle, both regimes accommodate and, in fact, recognize particular regulatory competences to protect common (environmental) concerns. However, as mentioned, neither regime definitively decides the matter of the EU's jurisdiction, thus directing us to a more detailed consideration of customary international law. Section V therefore explores customary law's cornerstone test of a 'substantial and genuine connection' between the regulating State and the regulated subject matter. This flexible requirement offers room for development beyond jurisdiction's Westphalian roots, in a world where the common interest should also carry weight. In adapting to the realities of global interdependence we seek an interpretation of States' jurisdictional rights that accommodates their obligations to respond to climate change as a common concern of mankind.

19 General Agreement on Tariffs and Trade 1994 (adopted 15 April 1994, entered into 1 January 1995) 1867 UNTS 154 (GATT 1994).

${ }^{20}$ For further discussion on the practice of interest-balancing within the customary law of jurisdiction see, C Ryngaert, Jurisdiction in International Law (2nd edn, OUP 2015) 150. 


\section{COMMON CONCERNS AND 'EXTRATERRITORIALITY'}

By 1988, climate protection had secured its place on the international agenda, with United Nations General Assembly (UNGA) Resolution 45/53 declaring climate change a 'common concern of mankind'. ${ }^{21}$ While admittedly still an emerging term, ${ }^{22}$ we argue in favour of the common concern as a distinct concept with a unique definition and legal implications. Section IIA seeks to define the common concern, exploring its relationship with the concepts of the global commons, common heritage of mankind and obligations erga omnes. Following a similar logic to that underlying obligations erga omnes, it is submitted that the recognition of common concerns brings with it common obligations for States. Section IIB explores the sources of these obligations, focusing on their application in the field of international environment law. As is the case with the EU's maritime plans, measures taken in response to common concerns are likely to raise issues of extraterritoriality. Burdened with a decidedly negative reputation, 'extraterritoriality' remains a contested concept in international law. Completing the conceptual framework, Section IIC explores this issue in more detail, clarifying the terminology used here.

\section{A. Defining the Common Concern}

Common concerns are essentially shared problems requiring a response in the form of collective action. As the term implies, the two core components are 'commonness' and an issue's nature as a 'concern'. Turning first to 'commonness', it is submitted that concerns are 'common' when they are shared by all individuals, irrespective of their nationality. ${ }^{23}$ As such, common concerns represent more than merely coinciding interests of individual States. ${ }^{24}$

${ }^{21}$ UNGA Res 43/53 (6 December 1988) UN Doc A/RES/43/53 (UNGA Res 43/53) art 1.

${ }^{22}$ The common concern has received increasing attention in the literature over the past decade. See eg C Voigt, 'Delineating the Common Interest in International Law' in W Benedek et al. (eds), The Common Interest in International Law (Intersentia 2014); T Cottier et al., The Principle of Common Concern and Climate Change, Working Paper, 2014/18 (2014) 293; D Shelton, 'Common Concern of Humanity' (2009) 1 Iustum Aequum Salutare 33; E Hey, 'Global Environmental Law: Common Interests and the Reconstruction of Public Space' in F Lenzerini and A F Vrdoljak (eds), International Law for Common Goods: Normative Perspectives on Human Rights, Culture and Nature (Hart Publishing 2014); F Biermann, “'Common Concern of Humankind": The Emergence of a New Concept of International Environmental Law' (1996) 34 AVR 1426; J Brunnée, 'Common Areas, Common Heritage and Common Concern' in D Bodansky, J Brunnée and E Hey (eds), The Oxford Handbook of International Environment Law (OUP 2007) 565.

${ }_{23}$ See further B Simma, 'From Bilateralism to Community Interest in International Law' (1994) 250 RdC 217; E Benvenisti, 'Sovereigns as Trustees of Humanity: On the Accountability of Sovereigns to Foreign Stakeholders' (2013) 107 AJIL 295; Voigt (n 22). See further on the cosmopolitan theory of normative individualism, R Pierik and W Werner (eds), Cosmopolitanism in Context: Perspectives on International Law and Political Theory (CUP 2010).

${ }^{24}$ See further on the distinction between 'coinciding state interests' and 'common' interests, J Brunnée, “"Common Interest" - Echoes from an Empty Shell? Some Thoughts on Common 
This is reflective of a shift in international law from a focus on individual State interests to those of the wider international community made up not only of States but of all human beings. ${ }^{25}$ This was described by the ICTY in the Tadic case, as a development from a 'State-sovereignty' to a 'human-beingoriented' configuration of the international community. ${ }^{26}$

Of course, such a definition of 'common' remains vulnerable to the criticism that not all individuals share the same values and interests, and therefore cannot be grouped into a collective 'international community' in which such interests are clearly delineated. While this may be the case, there are arguably some matters of such a fundamental nature that they can be considered 'common', the primary one being collective survival. ${ }^{27}$ Adding a functional element, a concern is also common when 'no single State can resolve the problems they pose, or receive all the benefits they provide'. ${ }^{28}$

A common concern can be characterized as a type of common interest that takes the form of a 'problem', ${ }^{29}$ targeting specific 'processes' or 'protective action'. ${ }^{30}$ This characteristic distinguishes common concerns from the linked concepts of the 'common heritage of mankind' and the 'global commons'. Global commons are areas outside of the jurisdiction of any State, such as the high seas, outer space, and the atmosphere. ${ }^{31}$ The common heritage of mankind is a broader concept, referring to shared ownership or control over resources of the 'common heritage', including those within the territory of individual States. ${ }^{32}$ Common concerns are typically issues of environmental law, as ecosystems are not neatly delineated according to State territory. ${ }^{33}$

Interests and International Environment Law' [1989] Max-Planck-Institut für ausländisches öffentliches Recht und Völkerrecht 791.

25 Simma (n 23) 81.

26 Prosecutor v Duško Tadić aka 'Dule' (Decision on the Defence Motion for Interlocutory Appeal on Jurisdiction) IT-94-1 (2 October 1995) [97].

27 This is in line with the ICJ's finding in Barcelona Traction, Light and Power Company, Limited (Belgium v Spain) Second Phase, (Judgment) [1970] ICJ Rep 32 (Barcelona Traction) [33], that erga omnes obligations arise 'by their very nature [...] in view of the importance of the rights involved'. Voigt (n 29) 17, argues that collective survival is 'the primary common concern'. See for a different view, Shelton (n 22) 35.

28 Shelton (n 22) 34. Common concerns are linked to the concept of global public goods (GPGs). GPGs are defined as non-rivalrous and non-excludable goods ('public'), which tend to be undersupplied at a global level as governments lack the incentive to produce them ('global'). This arises due to governments' reciprocal lack of confidence that the others will share the costs of production, combined with the fact that the objective of production will only be achieved when all act collectively. A key example of this is climate change mitigation. See further D Bodansky, 'What's in a Concept? Global Public Goods, International Law and Legitimacy' 23 EJIL 651 (2012); N Krisch, 'The Decay of Consent, International Law in the Age of Global Public Goods' (2014) 108 AJIL 1; F Caffagi and D Caron, 'Global Public Goods amidst a Plurality of Legal Orders: A Symposium' (2012) 23 EJIL 643.

${ }^{29}$ C Voigt, 'Delineating the Common Interest in International Law' (n 22) 19.

30 Brunnée (n 22) 564.

31 EA Clancy, 'The Tragedy of the Global Commons' (1998) 5 IndJGlobalLegalStudies 601, 3.

32 Cottier et al. (n 22) 13.

33 Concerns need not be limited to environment however, see eg C Beitz, 'Human Rights as a Common Concern' (2001) 95 AmPoliSciRev 269, 281. 
At first glance, common concerns bear considerable resemblance to obligations erga omnes, which are obligations owed by all States to the international community as a whole. ${ }^{34}$ Such obligations arise in relation to certain rights of such importance that all States have a 'legal interest' in their protection. ${ }^{35}$ Similarly to the ICTY in Tadić, Crawford suggests that obligations erga omnes are owed to the 'international community' made up not only of States, but also international organizations and natural legal persons. ${ }^{36}$ This view would further align the concept with common concerns. There is, however, a difference in emphasis. Erga omnes obligations are generally related to issues of State responsibility rather than State jurisdiction. They become relevant when one State's responsibility is invoked by another State that is not directly injured by a violation but has an interest in compliance. ${ }^{37}$

Importantly, common concerns are linked to obligations erga omnes, as recognition of the former may well trigger the latter. This was explained in Belgium v Senegal, where the ICJ held that 'the common interest implies that the obligations in question are owed by any State party to all the other States parties to the Convention'. ${ }^{38}$ Arguably then, where a common concern, as a type of common interest, has been recognized in a treaty containing obligations aimed at its protection, then these are obligations erga omnes partes. It remains unclear, however, to what extent a common interest existing only in customary international law may give rise to general obligations erga omnes. ${ }^{39}$

\section{B. State Obligations to Respond to Common Concerns?}

As the common concern is a newly evolving concept, its precise legal consequences are yet to crystallize in legal doctrine. Fundamentally, the notion that a common interest implies common obligations seems consistent with the rationale of erga omnes obligations provided in Belgium v Senegal. Based on the current state of the law, we argue that one can discern, at the very least, a duty to cooperate and to consider the interests of other legally equal States and their citizens when taking action affecting common

34 Barcelona Traction (n 27) [33].

35 ibid.

36 See further J Crawford, Articles on Responsibility of States for Internationally Wrongful Acts (United Nations 2012) < http://legal.un.org/avl/pdf/ha/rsiwa/rsiwa_e.pdf >; E de Wet, 'Invoking Obligations Erga Omnes in the Twenty-First Century: Progressive Developments Since Barcelona Traction' (2013) 37 SAYIL 1.

37 See ILC, 'Draft Articles on Responsibility of States for Internationally Wrongful Acts' (2001) UN Doc A/56/10 (DARS), art 48.

38 Questions Relating to the Obligation to Prosecute or Extradite (Belgium v Senegal). (Merits) ICJ Rep 422 [38].

39 See for further discussion on shared values and customary erga omnes obligations, Shelton (n 22) 39; C Ryngaert, Inaugural Lecture - Unilateral Jurisdiction and Global Values (Eleven International Publishing 2015) 39, 42-4. 
concerns. ${ }^{40}$ It is further submitted that, under international environmental law, States have a due-diligence obligation to anticipate, prevent and minimize the aggravation of common environmental concerns. ${ }^{41}$ The following paragraphs will explore key sources of these general obligations, and consider their more specific operationalization in relation to climate change.

While international law was traditionally founded on the individualistic, 'negative' rules of delimitation and abstention, the positive duty to cooperate now plays an increasingly central role. ${ }^{42}$ Article 1 of the UN Charter, as the "magna carta of cooperation', notes the key UN aim '[t]o achieve international co-operation in solving international problems of an economic, social, cultural, or humanitarian character' ${ }^{43}$ Further support can be found in Principle 4 of the supplementary Declaration of Friendly Relations and Cooperation among States. ${ }^{44}$ In fact, in the MOX Plant Case, the International Tribunal for the Law of the Sea (ITLOS) found the duty to cooperate to be a 'fundamental principle in [...] general international law'. ${ }^{45}$ According to Perrez, this duty is inherent in sovereignty itself, which today is generally accepted to include certain responsibilities as well as State powers. ${ }^{46}$ While a State's primary responsibility is to its citizens, the recognition of community interests has brought with it recognition of sovereign responsibilities towards the 'higher' international community. ${ }^{47}$

States must also take into account the interests of the international community when taking action on a national level likely to affect others. This flows from of the basic norm of sovereign equality, according to which a State's sovereign

40 Benvenisti (n 23) 301. See also Hey (n 22) 45, 45: 'the common concern requires that states within their territory and over activities subject to their jurisdiction adopt measures to curtail environmental degradation and that states assist each other in addressing these problems'.

41 See for a similar wording, Committee on Legal Principles Relating to Climate Change, 'Declaration of Legal Principles Relating to Climate Change', International Law Association Resolution 2/214 (2014), Annex: ILA Principles Relating to Climate Change-Draft Articles (ILA Draft Articles Relating to Climate Change) art 7A.

42 See further R Wolfrom, 'International Law of Cooperation' in R Wolfrum (ed), Max Planck Encyclopaedia of Public International Law (2008) available at <http://opil.ouplaw.com/home/ EPIL> [7].

${ }^{43}$ Charter of the United Nations (adopted 26 June 1945, entered into force 24 October 1945) 1 UNTS XVI (UN Charter) art 1(3).

${ }^{44}$ Declaration on Principles of International Law concerning Friendly Relations and Cooperation among States in accordance with the Charter of the United Nations, UNGA Res 2625 (XXV) (24 October 1970) UN Doc A/RES/25/2625, Principle 4.

${ }^{45}$ MOX Plant (Ireland v United Kingdom) (Provisional Measures, Order of 3rd December 2001) ITLOS Reports 2001 [82].

46 See eg F Perrez, Cooperative Sovereignty: From Independence to Interdependence in the Structure of International Environmental Law (Springer 2000) 332; A Hertogen, 'Letting Lotus Bloom' (2016) 26 EJIL 901, 924; M Koskenniemi, 'What Use for Sovereignty Today?' (2011) 1 AsianJIL 61, 63.

${ }_{47}$ This is clearly visible in the rise of the 'responsibility to protect' doctrine. See further Koskenniemi (n 46) 65; A Orford, International Authority and the Responsibility to Protect (CUP 2011); S Stec, 'Humanitarian Limits to Sovereignty: Common Concern and Common Heritage Approaches to Natural Resources and Environment' (2010) 12 IntCLR 361, 364. See also the Separate opinion of Vice-President Weeramantry, in ICJ, Case concerning the Gabcikovo-Nagymaros Project (Hungary/Slovakia) (Merits) ICJ Rep (1997) 7. 
rights are inherently limited by the equal sovereignty of other States. ${ }^{48}$ As such, ' $[t]$ he existence of a number of sovereignties side by side places limits on the freedom of each State to act as if the others did not exist'. ${ }^{49}$ From a more 'humanity-oriented' perspective, it could be argued that national regulators have sovereign 'other-regarding' obligations towards foreign individuals, where this may impact their right to self-determination. ${ }^{50}$ The precise form of these obligations will depend on the applicable law.

International environmental law contains several due-diligence obligations which could be seen to operationalize a State duty to consider 'others' in relation to common environmental concerns. The first is the customary duty to ensure that activities conducted within a State's jurisdiction do not cause damage outside of their territories. ${ }^{51}$ Another relevant principle is that of precaution, which provides that in cases of 'threats of serious or irreversible damage', 'lack of full scientific certainty' shall not serve as a justification for failing to prevent environmental degradation. ${ }^{52}$ While the former has traditionally been applied to more isolated transboundary harm, it is now well accepted that the no harm principle covers more complex harms attributable to multiple States, a fact confirmed by its incorporation in the preamble of the UNFCCC. ${ }^{53}$

In relation more specifically to climate change, the International Law Association (ILA) Draft Articles Relating to Climate Change provide that States have a due diligence obligation to "take all appropriate measures to anticipate, prevent or minimise the causes of climate change, especially through effective measures to reduce greenhouse gas emissions'. ${ }^{54}$ Some authors suggest that this due-diligence threshold may go beyond the obligations contained in the Kyoto (and Paris) frameworks, as neither are currently sufficient to prevent a dangerous rise in the global temperature. ${ }^{55}$ Indeed, the recently published 'Oslo Principles' go so far as to argue that

${ }^{48}$ UN Charter (n 43) art 2(1).

49 Legality of the Threat or Use of Nuclear Weapons (Advisory Opinion) [1996] ICJ Rep 226, 393-394, Dissenting Opinion of Judge Shahabuddeen.

${ }^{50}$ Benvenisti (n 23) 316; UN Charter (n 43) art 1(2).

51 See UNCED, Declaration of the United Nations Conference on the Human Environment (1972) UN Doc A/Conf.48/14/Rev (Stockholm Declaration) Principle 21, and the Trail Smelter Arbitration (1941) 3 UN Rep Int'l Arb Awards 1905. See also UNEP, Environmental Law: Guidelines and Principles, No 2, Shared Natural Resources (Nairobi 1978) Principle 3.

52 See eg UNCED, Rio Declaration on Environment and Development (1992) UN Doc A/ Conf.151/26 (vol. I), (Rio Declaration) Principle 15; United Nations Framework Convention on Climate Change, 1771 UNTS 107 (1992) (UNFCCC) art 3(3).

${ }^{53}$ See further J Peel, 'The Practice of Shared Responsibility in Relation to Climate Change' (2015) SHARES Research Paper No $71<w w w . s h a r e s p r o j e c t . n l>$. Peel refers to the broad interpretation of 'transboundary harm' in the Draft Articles on Prevention of Transboundary Harm from Hazardous Activities, ILC, 'Report on the work of its fifty-third session' (2001) UN Doc A/56/10, art 2(c).

${ }^{54}$ ILA Draft Articles Relating to Climate Change (n 41) art 7(A)2. See also Biermann (n 22) 443.

55 Peel (n 53) 20; C Voigt, 'State Responsibility for Climate Change Damages' (2008) 77 NordicJIntlL 1, 5 . 
States have a legal obligation to achieve set, per capita emission reductions. ${ }^{56}$ This 'permissible GHG quantum' is calculated based on scientific data on the maximum amount of GHG that can 'safely' be emitted over a period of time. ${ }^{57}$ Importantly, States' respective obligations are to be adjusted according to the principle of common but differentiated responsibility (CBDR) so that more developed States shoulder a financial burden proportionate to their capabilities and historical contributions. ${ }^{58}$ Notably, while the Oslo Principles purport to clarify existing legal obligations, they have not in themselves been incorporated into positive law. ${ }^{59}$

The above analysis demonstrates considerable support for a sovereign duty to cooperate and consider the interests of other States and non-nationals in the context of common concerns. This extends to a due-diligence obligation to prevent and minimize their contribution to common environmental concerns, including the GHGs causing climate change. It would thus seem only consistent that States' obligations to respect 'others' embedded in principles of public international and international environment law be reflected in the law of State jurisdiction. While this may seem intuitive, the relationship between States obligations and State jurisdictional rights to respond to common concerns is far from clear-cut. This is largely due to the fragmented and decentralized development of the law of jurisdiction, based on the Westphalian premise of independent States. With their high premium on sovereign independence, jurisdictional rules are designed to ensure reciprocal respect for territorial boundaries. Measures with 'extraterritorial' effects may threaten the freedom of other States and are suspected of jurisdictional overreach. ${ }^{60}$ This is typical of measures targeting transboundary issues, particularly common environmental concerns, the EU maritime MRV being a key example.

Within the law of jurisdiction, 'extraterritoriality' remains a contested concept. ${ }^{61}$ In a neutral sense, it may be understood in relation to States or regional organizations, as 'encompassing the area beyond its territory'. ${ }^{62}$ Views differ as to whether measures addressing extraterritorial conduct, such as emissions on the High Seas, are necessarily also 'extraterritorial measures' or an 'exercise of extraterritorial jurisdiction'. Before proceeding, it is thus

\footnotetext{
56 Oslo Principles on Global Climate Change Obligations (1 March 2015) Osloprinciples.org, $<$ www.osloprinciples.org/principles> (Oslo Principles) Principles 1, $14 . \quad 57$ ibid art 3.

58 ibid Principle 14.

59 The Oslo Principles have been drafted by legal experts who seek to 'identify and articulate a set of Principles' that comprise States' 'essential obligations' to 'avert the critical level of global warming' (ibid, rec 1).

${ }^{60}$ ILC, Report of the International Law Commission on the Work of its 58th Session (2006) UN Doc A/61/10 (2006 ILC Report on Extraterritorial Jurisdiction) 518.

${ }^{61}$ See for some examples: M Kamminga, 'Extraterritoriality' in Max Planck Encyclopaedia of Public International Law (n 42); International Bar Association, 'Report of the Taskforce on Extraterritorial Jurisdiction' (6 February 2009) (IBA Report on Extraterritorial Jurisdiction); 2006 ILC Report on Extraterritorial Jurisdiction (n 60) 518.

622006 ILC Report on Extraterritorial Jurisdiction (n 60) 518.
} 
valuable to clarify our understanding of this issue within the broader context of customary international law.

\section{C. 'Extraterritoriality' in the Law of State Jurisdiction}

Extraterritorial jurisdiction has been defined broadly as 'referring to the exercise of sovereign power or authority by a State outside of its territory' ${ }^{63}$ Here, a distinction must be drawn between prescriptive jurisdiction, which pertains to a State's competence to 'to adopt legislation providing norms of conduct which govern persons, property or conduct' ${ }^{64}$ and enforcement jurisdiction, which describes a State's competence to ensure compliance with a State's laws. ${ }^{65}$ While enforcement jurisdiction is strictly territorial, there are several recognized bases in international law for States to prescribe measures that extend beyond their territory. ${ }^{66}$ There remains, however, considerable disagreement as to precisely when such a jurisdictional assertion should be characterized as 'extraterritorial', and the implications this has for a measure's legality.

A more traditional view approaches extraterritoriality through the lens of the classical bases of jurisdiction. To start with, while States can clearly regulate domestic conduct occurring entirely within their territory, in some circumstances they may also assert jurisdiction when a constituent element of an activity is only initiated or completed within their territory (subjective and objective territoriality respectively). ${ }^{67}$ It is also generally accepted that States may legislate with regard to their nationals abroad (nationality principle) and to acts which threaten essential State interests (protective principle). In unique cases, States may also regulate 'certain conduct committed by foreigners against foreigners, outside its territory and not implicating that State's essential interests'. ${ }^{68}$ These are generally crimes of such a grave nature that all States have jurisdiction (universality principle). On this view, the customary bases of nationality, protection and universality are seen as 'extraterritorial' bases or principles, supporting jurisdictional assertions. Notably, these classical jurisdictional principles, while well-recognized in legal theory, are far from clear-cut and consistently applied in practice. ${ }^{69}$ Today it is therefore generally accepted that what is required for a valid

${ }^{63}$ ibid 516. See also Kamminga (n 61) [1].

${ }^{64} 2006$ ILC Report on Extraterritorial Jurisdiction (n 60) 517-8; Restatement (Third) of the Foreign Relations Law of the United States, vol. 1, (American Law Institute Publishers 1986) (US 3rd Restatement) section 401(a).

${ }_{65} 2006$ ILC Report on Extraterritorial Jurisdiction (n 60) 518; US 3rd Restatement (n 64) section $401(\mathrm{c})$.

${ }^{66}$ Kamminga (n 61) [8].

${ }^{67}$ V Lowe and C Staker, 'Jurisdiction' in MD Evans (ed), International Law (3rd edn, OUP 2010) 320-3; C Ryngaert, Jurisdiction in International Law (n 20) 78-80.

68 'IBA Report on Extraterritorial Jurisdiction' (n 61) 14. See for further discussion R O'Keefe, 'Universal Jurisdiction Clarifying the Basic Concept' (2004) 2 JICJ 735.

${ }^{69}$ Kamminga (n 61) [16]; IBA Report on Extraterritorial Jurisdiction (n 61) 11. 
assertion of prescriptive jurisdiction is a 'sufficient nexus' or 'substantial and genuine connection' between the legislating State and the regulated subject matter at issue. ${ }^{70}$ The classical principles can provide, either together or individually, evidence of such a link. The 'substantial and genuine connection' requirement will be discussed further below.

Another view is that measures taking into account foreign conduct are not 'extraterritorial' when there is a 'territorial link' or connection, even where this is very weak. Joanne Scott for example, argues that such measures are instances of 'territorial extension' of State or EU law, and can still be based on the territoriality principle. ${ }^{71}$ The controversial Air Transport Association of America (ATAA) case of the Court of Justice of the EU (CJEU) appears to support this conclusion. ${ }^{72}$ There, the Court was asked to determine whether the EU Aviation Directive (2008/101/EC) which expanded the EU Emissions Trading Scheme (ETS) to include aviation emissions was 'extraterritorial' and thus in violation of international law. ${ }^{73}$ The territorial scope of the Aviation Directive is comparable to that of the present maritime MRV, taking into account carbon emitted throughout the entire duration of the journey, including above the High Seas and over the territory of other States. The Court did not consider this to give rise to extraterritoriality, holding that as the aircraft landing and departing from EU aerodromes were 'physically in the territory' of one of the Member States, they were subject to the 'unlimited jurisdiction' of that Member State and the Union. ${ }^{74}$

Contrastingly, from yet another perspective, a measure is to be qualified as extraterritorial precisely because it addresses conduct outside of the territory of the forum State. ${ }^{75}$ This approach differs on two key points from the findings in the $A T A A$ case. Firstly, it draws a clearer distinction between prescriptive and enforcement jurisdiction, both of which require a valid basis under international law. Measures which condition the import or export of goods and services on conduct and circumstances abroad are concerned with extraterritorial conditions. $^{76}$ The legislation itself requires a basis under international law, the absence of which can constitute an international wrong. ${ }^{77}$ The fact that such measures are only imposed at the border is a question of enforcement, which

${ }^{70}$ R Jennings and A Watts, Oppenheim 's International Law (9th edn, OUP 1992) 456-8. See for further discussion and references fn 199.

71 J Scott, 'Extraterritoriality and Territorial Extension in EU Law' (2014) 62 AJIL 87.

72 ATAA Case (n 14).

73 Aviation Directive (n 12) amending, Parliament and Council (EU) Directive 2003/87/EC establishing a scheme for greenhouse gas emission allowance trading within the Community and amending Council Directive 96/61/EC [2003] OJ L 275 (ETS Directive).

${ }_{74}$ ATAA Case (n 14) [124]-[125].

75 Ringbom (n 11) 626; Hermeling et al. (n 16) 13; Bäuerle et al. (n 16) 84.

76 See further C Ryngaert and H Ringbom, 'Introduction: Port State Jurisdiction: Challenges and Potential' (2016) 31 IJMCL 379, 382-3; L Bartels, 'Article XX of GATT and the Problem of Extraterritorial Jurisdiction - The Case of Trade Measures for the Protection of Human Rights' (2002) 36 JWT 353, 378.

772006 ILC Report on Extraterritorial Jurisdiction (n 60) 518; Kamminga (n 61) [7]. 
requires its own valid basis in international law, as well as a valid act of prescriptive jurisdiction. Secondly, measures which do take into account extraterritorial conduct or circumstances are not automatically considered illegal. This will depend on whether a State can demonstrate a 'substantial and genuine connection' with help from other bases of jurisdiction. This last approach will be taken here, however, to avoid confusion, this article uses the phrase measures with an 'extraterritorial element'. ${ }^{78}$

This raises the threshold question of when a measure contains a sufficient degree of external influence to constitute a relevant 'extraterritorial element', triggering questions of jurisdiction. This is especially important with regard to outward-looking market-based-measures, which do not, strictly speaking, force foreign actors to comply, but rather provide a (strong) incentive for them to do so. ${ }^{79}$ While a full exploration of this discussion goes beyond the scope of this article, it is submitted, along the lines proposed by Bartels in the context of trade law, that a measure has a relevant extraterritorial element when its application is 'objectively defined' by foreign circumstances. ${ }^{80}$ Thus, even where a measure has been framed around territorial conduct or presence (ie 'territorialized'), such as presence in an aerodrome, the actual requirements to be met at that point relate to extraterritorial events. Notably, this 'objective operation' threshold does not encompass all external effects. It requires that the legislation contemplate and condition, either directly or indirectly, specific extraterritorial events. This is consistent with the sovereigntyoriented frame, as economic pressure can be just as compelling as physical pressure in shaping the behaviour of foreign actors. In fact, economic pressure, when applied over time, can lead to even greater, more structural changes in the activities of foreign actors. It is irrelevant in this regard, whether the financial pressure takes the form of a sanction or neutral trade restriction. ${ }^{81}$

Section II has sought to clarify the concepts of 'common concerns' and 'extraterritoriality' in international law. These issues are related, as measures taken in response to common concerns tend to contain extraterritorial elements to bolster their effectiveness. Doctrinally however, there remains a conflict of paradigms between community-oriented common concerns managing interdependence, and the State-centric law of jurisdiction promoting independence. For States this may lead to a problematic gap between their obligations to respond to common concerns and their jurisdictional rights to do so. Still, these two frameworks need not be incompatible. It will be shown

\footnotetext{
78 See for the similar phrase 'foreign element', ICJ, Case Concerning Barcelona Traction, Light and Power Co. Ltd. (Belgium v Spain) (Merits) [1970] ICJ Rep 3, 105.

79 See eg L Ankersmit, J Lawrence and G Davies, 'Diverging EU and WTO Perspectives on Extraterritorial Process Regulation' (2012) 21 Minnesota Journal of International Law online 14, 25.

${ }^{80}$ See further Bartels (n 76) 381. Joanne Scott uses a similar formulation in her definition of territorial extension, which occurs when the 'relevant regulatory determination' is formed, 'as a matter of law, by conduct or circumstances abroad' (Scott (n 71) 90). ${ }^{81}$ Bartels (n 76) 381.
} 
that the jurisdictional rules applicable here can and do accommodate measures protecting the climate as a common concern. Turning to the case at hand, Section III will first explore the 'extraterritorial elements' of Regulation 2015/757 giving rise to the need for jurisdictional justification.

III. PROVOCATIVE CLIMATE PROTECTION: THE ‘EXTRATERRITORIAL ELEMENTS’ OF THE

\section{EU'S MARITIME MEASURES}

The EU has made no secret of its plans to go it alone. In 2009, frustrated by the slow pace of international negotiations, it notified the international community that should the IMO fail to reach an international agreement by 2011 , it would proceed to include maritime emissions in its own community target. ${ }^{82}$ By this time, the IMO had made some progress, amending MARPOL Annex VI to include the binding Ship Energy Efficiency Management Plan (SEEMP) and Energy Efficiency Design Index (EEDI) for new ships. ${ }^{83}$ However, the EU's environmental impact assessment predicted that even with these measures, EU-related emissions would increase more than 50 per cent by 2050 compared to 1990 -levels. ${ }^{84}$ What was needed was an instrument to cut emissions for the international maritime transport sector as a whole. ${ }^{85}$ The present maritime monitoring, reporting, and verification regulation (MRV) signals the first step, providing the data necessary for the operation of a market-based-measure (MBM) for maritime emissions. ${ }^{86}$ Notably, the MRV itself is expected to achieve up to two per cent emission reductions as a freestanding measure. ${ }^{87}$ Regulation 2015/757 and the planned MBMs will now be examined in more detail.

\section{A. Regulation $2015 / 757$}

Regulation 2015/757 applies to all ships above 5000 gross tonnage involved in commercial transportation, 'regardless of their flag'. ${ }^{88}$ 'Companies' responsible

\footnotetext{
82 Parliament and Council (EU) Directive 2009/29/EC amending Directive 2003/87/EC so as to improve and extend the greenhouse gas emission allowance trading scheme of the Community [2009] OJ L 140/63. See also Parliament and Council (EU) Decision 406/2009/EC on the effort of Member States to reduce their greenhouse gas emissions to meet the Community's greenhouse gas emission reduction commitments up to 2020 [2009] OJ L 140/136.

${ }^{83}$ Resolution MEPC.203(62), making mandatory the Energy Efficiency Design Index (EEDI) for new ships; Ship Energy Management Plan (SEEMP) for all ships in Annex VI of the International Convention for the Prevention of Pollution from Ships, 1340 UNTS 184 (1973).

${ }^{84}$ See COM (2013)479 (n 8) 2; Commission (EU), 'Executive Summary of the Impact Assessment Accompanying the Document Proposal for a Regulation of the European Parliament and of the Council on the Monitoring, Reporting and Verification of Carbon Dioxide Emissions from Maritime Transport and Amending Regulation (EU) No 525/2013' (Commission Staff Working Document) SWD(2013) 236 final, 28 June 2013 (Executive Summary of the MRV Impact Assessment). $\quad 85$ Executive Summary of the MRV Impact Assessment (n 84) 2.

${ }_{86}$ COM (2013)479 (n 8) 7-8. $\quad{ }_{87}$ Regulation 2015/757 (n 7) 13; COM (2013)479 (n 8) 5.

${ }^{88}$ Regulation $2015 / 757$ (n 7) rec 13 \& art 1,3(d). While originally it was suggested that several GHGs should be included, the final MRV only covers $\mathrm{CO}_{2}$ emissions. For the failed draft see:
} 
for the ships' operation are required to monitor the $\mathrm{CO}_{2}$ emitted during voyages to, between, and from ports under the jurisdiction of an EU Member State as of 2018. ${ }^{89}$ This must be done using approved technologies in accordance with one the of four standard monitoring methods listed in Annex I. ${ }^{90}$ Companies must provide the Commission with a 'monitoring plan' by 2017, detailing how they will meet these requirements (Article 13). As of 2019, companies must then provide emissions reports to the Commission and the concerned flag State authorities, documenting all required information for each ship during the previous reporting period (Article 11(1)). 'Verifiers', appointed by national accreditation authorities, must approve both the monitoring plans and resulting reports before they can be sent to the Commission. ${ }^{91}$

Ships are obliged to carry a valid 'document of compliance' evidencing that they have met these conditions when arriving at, within, or departing from a port under EU jurisdiction. ${ }^{92}$ Each EU Member State is further instructed to take 'all the measures necessary to ensure compliance of ships flying its flag' (Article 19 (1)). Article 19(2) requires Member States to ensure that 'any inspection of a ship in a port under its jurisdiction' is done in accordance with Directive 2009/16/EC on Port State Control Procedures. Importantly, Article 20(1) requires Member States to set up and impose an 'effective, proportionate and dissuasive' penalty system for ships that fail to comply. As noted by Churchill, while one would expect flag States to impose sanctions, this provision does not preclude, and in fact appears to require, port State action, also in relation to ships of non-EU nationality. ${ }^{93}$ Member States of the port of entry may further issue an expulsion order for ships failing to comply for two or more consecutive reporting periods (Article 20(2)).

On the face of it, the Regulation only attaches sanctions to a failure to produce a certificate of compliance when in EU territory. Indeed, Marten argues that such an MRV concerns the territorial provision of information, which is not 'stamped' with the location where it came into being. ${ }^{94}$ This distinction may not, however, be a reliable way of signalling suspect, 'extraterritorial' measures. Provisions formally framed as territorial requests for information, may, de facto, operate

Committee on the Environment, Public Health and Food Safety, 'Draft Report on the proposal for a regulation of the European Parliament and of the Council on the monitoring, reporting and verification of carbon dioxide emissions from maritime transport and amending Regulation (EU) No 525/2013' (Draft Report) (8 November 2013) 2013/0224(COD).

${ }_{89}$ Regulation $2015 / 757$ (n 7) arts 2, 4, 8, 9.

90 The four approved methods are: the use of Bunker Fuel Delivery Notes, bunker fuel tank monitoring on-board, flow meters for applicable combustion processes or direct emission measurements (ibid Annex 1). Annex II specifies how companies should collect the 'other relevant information' instrumental to the monitoring itself, such as the date and time of departure and the distance travelled. $\quad 91$ ibid art 3(f), 13, $15 . \quad 92$ ibid art 3(h), 17, 18.

${ }_{93}$ R Churchill, 'Port State Jurisdiction Relating to the Safety of Shipping and Pollution from Ships_-What Degree of Extra-territoriality?’ (2016) 31 IJMCL 442, 456.

94 B Marten, 'Port State Jurisdiction over Vessel Information: Territoriality, Extra-Territoriality and the Future of Shipping Regulation' (2016) 31 IJMCL 470, 489. 
as extraterritorial conduct requirements. ${ }^{95}$ For example, in the context of the present MRV, companies will only be able to prove compliance if they have abided by EU information collection methods when abroad. This constitutes a relevant extraterritorial element, triggering the need for the EU to demonstrate a 'substantial and genuine connection' to the regulated subject matter.

\section{B. Possible Market-Based Measures}

As discussed, the MRV is only the first step towards a further MBM aimed at harmonizing the objectives of profit-making and pollution reduction. ${ }^{96}$ At the time of writing, the EU is yet to decide on the design of such an MBM but in its 2013 Communication (COM (2013) 479) it announced its preferred options. The first is a maritime ETS (METS) similar to that envisioned for aviation emissions. ${ }^{97}$ Under this cap-and-trade scheme, operators are allotted a set amount of carbon credits based on specific emission reduction targets. Less energy-efficient operators whose emissions exceed their allotted targets are then forced to buy credits from other companies with a surplus. A maritime ETS with the same scope as the MRV would include in its calculations $\mathrm{CO}_{2}$ emitted outside EU territory. As the measure imposes a cumulative cost on foreign emissions, it contains a clear extraterritorial element.

A second possible MBM is a 'target-based compensation fund' which would set the same target as a METS for an entire fleet, to be monitored by a 'sectorwide entity'. ${ }^{98}$ This entity would have an obligatory contractual relationship with the fleets, who would have to pay excess emissions charges and a membership fee into the fund, to be invested in energy efficiency. ${ }^{99}$ Where the specific targets take into account the total distance travelled to or from EU ports, this would present similar jurisdictional concerns as a maritime ETS. ${ }^{100}$ As was the case with aviation emissions, it is likely that the Union will meet greater resistance when it comes to implementing the further stages of its plan. In order to stand up to political criticism, it is important that the design of the final MBM be compliant with international law. The following section will therefore consider the more specific legality issues under the LOSC and relevant world trade law.

95 Bäuerle et al. (n 16) 85 go so far as to argue that such a re-characterization would be 'an unlawful circumvention of the general principles of international law'.

96 COM (2013)479 (n 8) 7. 97 ibid.

98 Executive Summary of the MRV Impact Assessment (n 84) 4.

99 ibid. The contractual agreement will furthermore 'include provisions in case of collective overshooting of the targets', however the communication leaves open what these will contain.

${ }^{100} \mathrm{COM}(2013) 479,7$ also includes the third option of a 'contribution based compensation fund', however this is voluntary in nature and would only be implemented in combination with one of the obligatory measures. 
IV. PERMISSIBILITY OF THE MRV AND MARKET-BASED MEASURES UNDER THE LAW OF THE SEA CONVENTION AND WORLD TRADE LAW

The EU's well-known maritime plans have already sparked discussion amongst scholars and research institutions. ${ }^{101}$ There, the primary focus has been on the permissibility of a possible maritime ETS under the LOSC and WTO law, and views have been divided. ${ }^{102}$ This section seeks to demonstrate that not only a maritime ETS, but also the present MRV and the possible target-based compensation fund are, in principle, permissible under both the maritime and trade regimes. However, it will also be shown that neither regime definitively answers the question of whether the EU has exceeded the limits of its jurisdiction. For this, we are directed towards customary international law, an area that has received less structured attention to date, and will thus be the focus of Section V.

\section{A. Permissibility under the Law of the Sea Convention}

As alluded to above, there is some disagreement as to whether the Law of the Sea Convention (LOSC) permits the EU's measures, particularly a maritime ETS. Those against emphasize the tensions with the freedom of navigation. They consider an METS to be an exercise of 'extraterritorial' rather than port State jurisdiction, requiring an explicit, alternative basis under the law of the sea. ${ }^{103}$ The argument then goes that there is no such explicit basis and, moreover, the EU measures would conflict with Article 92 LOSC, which enshrines the principle of exclusive flag State jurisdiction over ships on the High Seas. An METS would violate this principle, as the EU Member States are regulating activities on the high seas of vessels not flying their flag. ${ }^{104}$ For this reason, the EU measures would also violate Article 89 LOSC which provides that no State may purport to subject the High Seas to its sovereignty. These authors may also point to Article 218 LOSC, which provides that port States may not institute proceedings pertaining to discharges occurring outside of their territorial waters or EEZ other than those 'in violation of applicable rules and standards', and thus arguably implies a contrario, that States or the EU are not competent to regulate other conduct on the high seas, let alone conduct that is not in violation of international standards. ${ }^{105}$

This article supports the alternative view that requiring an explicit basis in the LOSC does not sufficiently consider the residual jurisdiction of States and regional organizations to set conditions for entry into their ports, which are,

\footnotetext{
101 See fn 16 for an overview of the literature.

102 See Ringbom (n 11); Hermeling et al. (n 16); Bäuerle (n 11); Kremlis (n 16); Murphy (n 16); Bäuerle et al. (n 16).

104 Hermeling et al. (n 16) 13.

103 Hermeling et al. (n 16) 13-14; Bäuerle et al. (n 16) 85. 105 ibid.
} 
after all, part of their territory. ${ }^{106}$ Under international law ships have no general right of access to foreign ports. ${ }^{107}$ Article 25(2) LOSC further provides that the coastal State has the right to take the necessary steps with respect to ships proceeding to internal waters to prevent any breach of the conditions to which the admission of those ships is subject.

Moreover, UNCLOS implicitly acknowledges port States' competence to regulate environmental matters, without providing a territorial limit. Article 211(3) LOSC recognizes the competence of coastal States (which port States also qualify as) to 'establish particular requirements for the prevention, reduction and control of pollution of the marine environment'. ${ }^{108}$ Maritime $\mathrm{CO}_{2}$ emissions can be considered 'pollution', as climate change and air pollution harm marine life and human health. ${ }^{109}$

In assessing port State jurisdiction to prescribe such measures, a distinction can be drawn between 'static', construction, design, equipment and manning (CDEM) standards and measures regulating operational pollution. ${ }^{110}$ Both the MRV and envisioned MBMs implicitly require vessels to be fitted with the equipment necessary for monitoring $\mathrm{CO}_{2}$ emissions, and thus contain CDEM standards. ${ }^{111}$ The requirements regarding the monitoring itself, as well as the reporting and attainment of verification and compliance documentation pertain to foreign conduct. While several IMO Conventions, in particular MARPOL, set CDEM standards for pollution prevention, ${ }^{112}$ Article 211(3) does not specify whether port State pollution measures are limited to those international standards. ${ }^{113}$ Furthermore, the IMO Conventions themselves do not contain relevant prohibitions on higher unilateral standards. ${ }^{114}$ No explicit territorial limits can be found in the LOSC as regards pollution reduction measures regulating vessel operation prior to port entry. ${ }^{115}$

Notably, it has been argued that unlike operational measures, CDEM standards are in fact territorial, as they are not primarily aimed at regulating

106 LOSC (n 15) art 2(1). See further Ringbom (n 11) 256. See also S Kopela, 'Port-State Jurisdiction, Extraterritoriality, and the Protection of Global Commons' (2016) 47 OceanDev\& IntlL 89.

107 Case concerning Military and Paramilitary Activities In and Against Nicaragua (Nicaragua $v$ United States of America) (Merits) [1986] ICJ Rep 3 [213].

108 LOSC (n 15) art 211(3)(f).

109 This is an 'effects-based' view, focusing on link between $\mathrm{CO}_{2}$ and climate change which is the core cause of environmental harm. See Bäuerle et al. (n 16) 91; LOSC (n 15) art 1(4).

110 See further Churchill (n 93) 443. 111 See Regulation 2015/757 (n 7) Annex I.

112 International Convention for the Prevention of Pollution from Ships (signed 2 November 1973, entered into force 2 October 1983) 1340 UNTS 62 (MARPOL).

113 Churchill (n 93) 450. An example of such a unilateral CDEM standard is Parliament and Council (EC) Regulation 417/2002 on the accelerated phasing-in of double-hull or equivalent design requirements for single hull oil tankers (as amended) [2002] OJ L64/1. 114 ibid.

${ }^{115}$ See further E Molenaar, 'Port State Jurisdiction: Toward Comprehensive, Mandatory and Global Coverage' (2007) 38 OceanDev\&IntlL 225. See also Ringbom (n 11) 625. 
vessels outside a State's territory. ${ }^{116}$ However, as vessels will have to comply with construction standards before arrival at port, there remains an 'extraterritorial element' to be considered in light of customary international law.

By not geographically limiting the marine environment that States can protect, the LOSC accommodates State measures taken to remedy environmental degradation. Indeed, Article 211(2) LOSC supplements this by requiring States to 'adopt laws and regulations for the prevention, reduction and control of pollution of the marine environment from vessels flying their flag'. These laws must have 'at least' the 'same effect as generally accepted international standards'.

Furthermore, the principle of exclusive flag State jurisdiction does not preclude port entry conditions. While still a point of discussion, the systemic logic and drafting history of the LOSC arguably indicate that Article 92 LOSC is concerned with enforcement rather than prescriptive jurisdiction for activities on the High Seas. ${ }^{117}$ For its part, the EU MRV instructs Member States to ensure compliance only of vessels flying their flag (Article 19(1)), and companies are only required to submit emission reports to the 'flag States concerned' (Article 11(1)). This is without prejudice to the port State competence to require a document of compliance upon entry (Article 19(2)), and sanction non-compliance (Article 20(1)(3)).

Arguably therefore, the LOSC allows States to legislate port entry conditions on prevention reduction and control of polluting activities, including activities contributing to climate change, which occur outside of their territories. These conditions remain subject to the reasonableness requirements of proportionality, non-discrimination (Article 227 LOSC), and non-abuse of rights (Article 300 LOSC), discussed in Section VB.

These diverging views illustrate the conflict of interests between the freedom of navigation and unilateral pollution reduction by port States. The LOSC sets out a general framework balancing these interests, with exclusive competences in territorial waters, and greater freedoms on the High Seas. However, precisely at the point of contact where foreign vessels enter territorial waters, the Convention says little, leaving open the question of the territorial limits of port State jurisdiction. Here, customary international law has an important role to play in clarifying the limits of States' regulatory competence. ${ }^{118}$

\footnotetext{
116 Churchill (n 93) 454. This rests on a somewhat different conception of 'extraterritoriality' than that used here (Section IIC).

117 A Honniball, 'The Exclusive Jurisdiction of Flag States: A Limitation on Pro-Active Port States?' (2016) 31 IJMCL 499.

${ }^{118}$ UN, Vienna Convention on the Law of Treaties (adopted 23 May 1969, entered into force 27 January 1980) 1155 UNTS 331 (VCLT), art 31(3)c. See further eg D Pulkowski, The Law and Politics of International Regime Conflict (OUP 2014). For a more general discussion on customary law and port state jurisdiction see, Molenaar (n 115) 229.
} 


\section{B. Permissibility under World Trade Law}

The EU measures must also pass the hurdles posed by the WTO Agreements governing barriers to trade. ${ }^{119}$ The MRV as well as both MBMs would raise tensions under the General Agreement on Tariffs and Trade (GATT) as they may unjustifiably erect obstacles to the international trade in goods. ${ }^{120}$ They may also face issues under the General Agreement on Trade in Services (GATS), where States have made commitments regarding access to and use of port facilities and maritime transport services. ${ }^{121}$ It has further been submitted that a METS could constitute a 'technical regulation' under the Technical Barriers to Trade (TBT) Agreement. ${ }^{122}$ To date, however, it remains unclear whether non product-related process and production methods (npr-PPMs) such as those in an ETS, 'lay down product characteristics or their related processes or production methods' (Annex 1.1), falling within the scope of the TBT Agreement. ${ }^{123}$ As the processes in the MRV and MBMs pertain to the vessels' operation irrespective of their goods, it seems unlikely that they have a 'sufficient nexus' with the products on board as required by the Appellate Body $(\mathrm{AB})$ in $E C$ Seals. ${ }^{124}$ The following section therefore does not address TBT, but limits its analysis to the GATT and GATS, which would otherwise continue to apply.

\footnotetext{
119 Marrakesh Agreement Establishing the World Trade Organization (15 April 1994) 1867 UNTS 154 (WTO Agreement), rec 1.

${ }^{120}$ GATT 1994 (n 19).

${ }_{121}$ General Agreement on Trade in Services (adopted 15 April 1994, entered into force 1 January 1995) 1869 UNTS 183 (GATS) art 1. See further Council for Trade in Services, 'Maritime Transport Services - Background Note by the Secretariat' (World Trade Organization 2010) S/C/W/315. Note, at the time of writing 23 WTO Members including the EU are negotiating the 'Trade in Services Agreement' (TiSA) which will include maritime transport. See for the EU position, European Commission, 'Trade in Services Agreement (TiSA)' (ec.europa.eu, 27 October 2016) $<$ http://ec.europa.eu/trade/policy/in-focus/tisa/>.

${ }^{122}$ Agreement on Technical Barriers to Trade (adopted 15 April 1994, entered into force 1 January 1995) 1868 UNTS 120. See for a TBT analysis of the EU aviation ETS, S R SánchezTabernero, 'For Whom the Bell Tolls: The EU ETS in Aviation under the TBT Agreement' (2015) 49 JWTL 781.

${ }^{123}$ This was left undecided during the TBT negotiations; see Committee on Technical Barriers to Trade, 'Negotiating History of the Coverage of the Agreement on Technical Barriers to Trade with regard to Labelling Requirements, Voluntary Standards and Processes and Production Methods Unrelated to Product Characteristics', Note by the Secretariat (29 August 1995) G/TBT/W11. The matter was later raised in WTO, European Communities - Measures Affecting Asbestos and Asbestos-Containing Products - Report of the Appellate Body (5 April 2001) WT/DS135/AB/R paras 169-175 (EC-Asbestos) [67]-[70]; and European Communities - Trade Description of Sardines - Report of the Appellate Body (23 October 2002) WT/DS231/AB/R [176].

${ }_{124}$ In EC-Seals the AB considered whether certain measures constituted 'technical regulations' concerning product characteristics. However it declined to complete the analysis on when a PPM has a 'sufficient nexus' to be 'related to' the product characteristics in the sense of Annex 1.1. (WTO, European Communities - Measures Prohibiting the Importation and Marketing of Seal Products Report of the Appellate Body (18 June 2014) WT/DS401/AB/R (EC-Seals) [5.12], [5.69]. See also US-Tuna (Mexico), which concerned labelling requirements for PPMs. (WTO, Appellate Body, United States - Measures Concerning the Importation, Marketing and Sale of Tuna and Tuna Products (13 June 2012) WT/DS381/AB/R (US-Tuna II (Mexico)). Note though, that the test regarding labelling in the second part of Annex 1.1 is arguably more flexible than the first part (see EC-Seals [5.14]).
} 
Looking in more detail at the possible violations, a distinction must be drawn between the target-based compensation fund as a fiscal measure ${ }^{125}$ and a maritime ETS (METS) which is arguably a non-fiscal measure. ${ }^{126}$ The compensation fund imposes costs on both EU and foreign fleets through membership fees and excess emission payments, the proceeds of which go to the EU. ${ }^{127}$ These costs are reflected in the price of the transported products and related services, affecting the conditions of competition. As such, the measure could be characterized as an internal charge on all products that have travelled by ship, triggered by the internal sale of the goods (Article III:2 GATT). ${ }^{128}$ Presumably, the membership fee will be the same for all EU and non-EU fleets and therefore in compliance with the national treatment (NT) requirement in Article III:2 GATT, and the 'most favoured nation' (MFN) requirement in Article I:1 GATT. However, assuming the fleets' emission reduction targets do not take into account their distance from the EU, the payments for excess carbon emissions would likely lead to problems. This is because companies transporting 'like' products from further away will be faced with higher compliance costs than those from closer-by, particularly EU Member States, in violation of Article III:2 GATT. ${ }^{129}$ This differentiation in compliance cost according to port of origin therefore also violates Article I:1 GATT's MFN principle, failing to accord the same 'advantage' to like products of all States. ${ }^{130}$

An ETS, on the other hand, can arguably be characterized as a regulation rather than a tax. This is because operators receive something of value (carbon credits) for the price they have to pay, the cost of which is set by the

\footnotetext{
${ }^{125}$ Note, however, in US-Tobacco the panel found that financial penalty provisions for the enforcement of domestic laws are not an 'internal tax or charge of any kind' in the sense of III:2, but rather an internal regulation in the sense of III:4. Should the excess emissions charges be considered a penalty, then the measure would constitute a non-fiscal measure and need to be assessed under art III:4 and XI GATT. (GATT, Panel Report, United States - Measures Affecting the Importation, Internal Sale and Use of Tobacco (4 October 1994) DS44/R (US-Tobacco).

126 For arguments favouring this characterization with regard to the aviation ETS see L Bartels, 'The Inclusion of Aviation in the EU ETS: WTO Law Considerations' (International Centre for Trade and Sustainable Development 2012) Issue Paper No 6, 9; J Pauwelyn, 'Carbon Leakage Measures and Border Tax Adjustments under WTO Law' in D Prévost and G van Calster (eds), Research Handbook on Environment, Health and the WTO (Edward Elgar 2012). See also the Opinion of Advocate General Kokott in the ATAA Case (n 14).

${ }_{127}$ This is consistent with the OECD definition of a tax: 'a compulsory unrequited payment to the government'. OECD, 'Glossary of Tax Terms' (www.oecd.org, 2016) <http://www.oecd.org/ctp/ glossaryoftaxterms.htm\#T>.

${ }_{128}$ The difference between border measures as being triggered by virtue of importation, compared to internal measures which are triggered by virtue of an internal factor or activity, was explained in WTO, AB Report, China - Measures Affecting Imports of Automobile Parts (12 January 2009) WT/DS339,340,342/AB/R [158] (China-Autos).

${ }_{129}$ For the definition of 'like products' see WTO, AB Report, Japan - Taxes on Alcoholic Beverages (1 November 2006) WT/DS8/AB/R.

${ }^{130}$ In EC - Bananas III (Guatemala and Honduras) the panel found that a measure 'grants an advantage' to a product when it creates 'more favourable competitive opportunities'. WTO, European Communities - Regime for the Importation, Sale and Distribution of Bananas - Panel Report (25 September 1997) WT/DS27/R [7.239]. On the characterization of 'advantage' as the lowest possible compliance cost, see Bartels (n 126) 12.
} 
market rather than the regulator. ${ }^{131}$ Again, the ETS would require operators from further away to surrender more credits than those closer by. Where a METS is construed as a border measure triggered by virtue of importation, ${ }^{132}$ this would likely violate the prohibition of quantitative restrictions in Article XI GATT. The higher cost for imports travelling from further away has the effect of altering the conditions of competition for like products from different origins. ${ }^{133}$ Alternatively, an ETS could be construed as an internal regulation, as it also applies to intra-EU voyages, and is triggered by the internal sale of the imported goods. ${ }^{134}$ A METS is then not immediately prohibited, but has to comply with the NT and MFN requirements in Articles III:4 and I:1 GATT respectively. ${ }^{135}$ However, for the same reasons as with the compensation fund, an ETS differentiating compliance costs according to origin would likely violate the above-mentioned provisions. ${ }^{136}$ The MRV itself could also be characterized as an internal regulation in the sense of Article III:4 GATT. As the standardized monitoring and reporting procedures do not differentiate compliance costs according to a product's origin, the measure appears to comply with Articles III:4 and I:1 GATT.

The EU instruments also constitute 'measures affecting trade in services' according to Article I:1 GATS. ${ }^{137}$ Again, a compensation fund and ETS differentiating amongst 'like' services according to distance travelled from the EU would likely modify the conditions of competition in favour of EUflagged vessels, violating the national treatment requirement in Article XVII GATS. ${ }^{138}$ They would also fail to accord 'treatment no less favourable'

131 See ibid for the analogous reasoning of Bartels on the Aviation ETS. See also the Opinion of Advocate General Kokott to the ATAA Case (n 14). $\quad{ }_{132}^{132}$ See also China-Autos (n 128) [158].

133 WTO, Colombia - Indicative Prices and Restrictions on Ports of Entry-Panel Report (20 May 2009) WT/DS366/R [7.258]-[7.275].

134 See for more nuanced considerations in relation to an Aviation ETS, Bartels (n 126) 11.

135 Under art III:4 GATT, 'less favourable treatment' is treatment which modifies the conditions of competition. WTO, AB Report, Korea-Measures Affecting Imports of Fresh, Chilled and Frozen Beef (2001) WT/DS161/AB/R (Korea-Beef).

136 In WTO, Dominican Republic - Measures Affecting the Importation and Internal Sale of Cigarettes - Report of the Appellate Body (25 April 2005) WT/DS302/AB/R [96], the AB held that 'the existence of a detrimental effect on a given imported product resulting from a measure does not necessarily imply that this measure accords less favourable treatment to imports if the detrimental effect is explained by factors or circumstances unrelated to the foreign origin of the product $[. .$.$] '. Here, however, the detrimental effect does appear 'explained' by circumstances$ relating to the foreign origin.

137 This is a broad provision. See art I:3(a) GATS: “measures by members" means measures taken by central, regional or local governments and authorities'. For the definitions of 'trade in services' and 'measures affecting trade in services' See further WTO, Canada-Certain Measures Affecting the Automotive Industry - Report of the Appellate Body (19 June 2000) WT/ DS142/AB/R (Canada-Autos (AB)).

138 For 'like services', see WTO, China-Certain Measures Affecting Electronic Payment Services-Panel Report (31 August 2012) WT/DS413/R [7]. The measures are not saved by footnote 10 which provides that specific commitments 'shall not be construed' to require compensation for 'inherent competitive disadvantages' as this does not cover measures 'which might modify the conditions of competition for services and service suppliers which are already disadvantaged due to their foreign character'. See WTO, Canada-Certain Measures Affecting 
(lowest possible compliance cost) to all like services and service suppliers, in violation of the MFN requirement in Article II GATS. ${ }^{139}$

Nevertheless, the WTO agreements contain well-recognized 'windows' for the consideration of non-trade interests, even when these have extraterritorial effects. ${ }^{140}$ These can be found in Articles XX GATT and XIV GATS, which contain exemptions for presumed violations which seek to serve certain public interest objectives. The following analysis focuses on GATT Article $\mathrm{XX}$, as it has received the most interpretation from the WTO Dispute Settlement Body, its text and rationale running largely parallel with that of the GATS. ${ }^{141}$ Section III.1 therefore examines the possibility for exemption offered by the environmental policy objectives in paragraph (b) (the 'protection of human, plant and animal life and health'), and paragraph (g) (the 'conservation of exhaustible resources') as conditioned by the requirements of the chapeau. ${ }^{142}$

\section{Article XX(b) GATT: 'necessary for the protection of human, plant and animal life or health'}

To provisionally qualify under Article XX(b), the maritime MRV and possible MBMs must pursue the objective of protecting human plant and animal life or health, and be 'necessary' for its achievement. The EU's well-documented policy objectives make clear that the measures are intended to reduce international maritime emissions for the benefit of the global climate and air quality. ${ }^{143}$ Based on IPCCC findings, the EU considers climate change mitigation instrumental to the protection of human and animal life and health. ${ }^{144}$ As regards more narrowly to air quality, in US-Gasoline $(A B)$ the $\mathrm{AB}$ found that reducing air pollution is a policy objective aimed at protecting life or health. ${ }^{145}$

the Automotive Industry - Panel Report (11 February 2000) WT/DS139/R [10.300] (Canada Autos (Panel)).

${ }_{139}$ In EC-Bananas III (Guatemala and Honduras) (n 130) [233]-[234]. The AB, at [241] clarified that this includes both de jure and de facto discrimination. The 'aim and effect' of a measure is irrelevant under both arts II and XVII GATS.

${ }^{140}$ WTO, United States - Import Prohibition of Certain Shrimp and Shrimp Products - Report of the Appellate Body (6 November 1998) WT/DS58/AB/R (US-Shrimp) [121]. See further C Voigt, 'WTO Law and International Emissions Trading: Is There Potential for Conflict?' (2008) 1 CCLR $52,59$.

${ }_{141}$ Note, art XIV GATS does not contain the general exemption found in art GATT XX $(\mathrm{g})$.

142 In US-Shrimp (n 140) [119]-[120], the AB clarified the order of the two-pronged test, starting with the requirements of the relevant paragraph and only then examining the chapeau requirements.

143 Regulation 2015/757 (n 7) rec 2; COM (2013)479 (n 8) 2.

144 European Commission, 'Climate Change and Consequences' (ec.europa.eu, 11 February 2016) <http://ec.europa.eu/clima/change/consequences/index_en.htm>. See also IPCC, 'Climate Change 2014 Synthesis Report Summary for Policymakers: Future Risks and Impacts Caused by a Changing Climate' (2014) Fifth Assessment Report (AR5) < https://www.ipcc.ch/report/ar5/syr/>.

145 WTO, United States - Standards for Reformulated and Conventional Gasoline-Appellate Body Report (20 May 1996) WT/DS2/AB/R [6.21] (US-Gasoline (AB)). 
The next issue is whether the measures are 'necessary', in the sense that they make a 'material contribution' to the achievement of their objective in the absence of an alternative, less trade restrictive measure. ${ }^{146}$ In Korea-Beef, the $\mathrm{AB}$ found that the 'relative importance' of the common interests or values that the measure purportedly serves may be considered. ${ }^{147}$ The more vital or important the common interests, the easier it would be to accept the measure as 'necessary'. Furthermore, in Brazil-Tyres it was recognized that 'certain complex public health or environmental problems may be tackled only with a comprehensive policy comprising a multiplicity of interacting measures. [...] Moreover, the results obtained from certain actions-for instance, measures adopted in order to attenuate global warming and climate change, [...] — can only be evaluated with the benefit of time.'148

According to the EU's impact assessment, both the MRV and planned MBMs can provide considerable GHG reductions compared to a business as usual scenario, evidencing a 'material contribution' to climate change mitigation. ${ }^{149}$ As mentioned, the MRV alone is expected to provide up to two per cent in annual GHG emission reductions and $€ 1.2$ billion net industry savings on fuel bills. ${ }^{150}$ Furthermore, a METS would be capable of achieving up to 21 per cent reduction in GHG emissions compared to the baseline scenario of only the existing instruments. ${ }^{151}$ For a target-based compensation fund, the predicted reduction is 16 per cent. ${ }^{152}$

Notably, the issue of carbon leakage poses a threat to the effectiveness of climate-related regulations, and it has been argued that lower carbon prices outside the EU may lead businesses to relocate. ${ }^{153}$ Yet avoiding carbon leakage is in fact a key reason for the expansive territorial scope of the EU's policy. If only intra-EU voyages were covered, vessels from outside of the EU would have a competitive advantage, which would be reflected in consumer prices. This would increase the consumption of cheaper, more $\mathrm{CO}_{2}$ intensive products and services, defeating the climate protection objective of the EU measure. ${ }^{154}$ There is a risk, however, that imposing costs on foreign producers may favour EU actors in a way that allows them to increase their own production of $\mathrm{CO}_{2}$. This was discussed in relation to border carbon adjustment taxes by Colares and Rode, who allude to the danger that EU lobbying efforts aimed at levelling the playing may result in the economically

146 WTO, Brazil - Measures Affecting Imports of Retreaded Tyres - Appellate Body Report (17 December 2007) WT/DS332/AB/R (Brazil-Retreaded Tyres) [151]. See also WTO, Korea Measures Affecting Imports of Fresh, Chilled and Frozen Beef - Appellate Body Report (10 January 2001) WT/DS161/AB/R, (Korea-Beef) [161]; and EC-Asbestos (n 123) [169]-[175].

147 Korea-Beef (n 146) [162]. ${ }_{148}$ Brazil-Retreaded Tyres (n 146) [151] (emphasis added).

149 Executive Summary of the MRV Impact Assessment (n 84) $2 . \quad 150$ ibid.

151 ibid 6.

152 ibid.

153 See further in relation to aviation emissions, J Meltzer, 'Climate Change and Trade-The EU Aviation Directive and the WTO' (2012) 15 JIEL 111.

${ }^{154}$ See for an analogous argument in relation to long-haul flights, ibid 119, 120. 
suboptimal imposition of tariffs or other trade restrictions. ${ }^{155}$ While this could certainly decrease the measures' 'material contribution' to climate change mitigation, these negative effects could be avoided by careful design of the tariff and scope of the envisioned MBMs. ${ }^{156}$

There must also be no less trade-restrictive alternative reasonably available to the proposed MBMs. ${ }^{157}$ In EC-Asbestos, the AB held that WTO members cannot reasonably be expected to adopt an alternative measure that would not allow them to achieve their desired level of protection. ${ }^{158}$ In 2009, the IMO recognized that technical and operational measures alone 'would not be sufficient to satisfactorily reduce the amount of GHG emissions' and an 'overwhelming majority' considered an MBM as a necessary supplement. ${ }^{159}$ Furthermore, an ETS is not by nature overly trade restrictive, as it has been recognized in Article 17 of the Kyoto Protocol as a legitimate means of limiting emissions. ${ }^{160}$ This evidences against the availability of a less traderestrictive alternative.

The third element of necessity recognized in Korea-Beef, namely the 'relative importance' of the objective, is particularly relevant here. ${ }^{161}$ As observed by Marceau and Trachtman, Korea-Beef broadened the necessity test to weigh the actual importance of the national (or EU) regulatory values against the trade values. ${ }^{162}$ This accommodates common concern protection by effectively lowering the 'necessity' threshold in Article XX(b). Applied to the present case, there can be no doubt that the mitigation of climate change is a 'vital' common interest meriting protection. ${ }^{163}$ Brazil-Tyres further indicates leeway in the time permitted to judge the effectiveness of the EU's mitigation measures. ${ }^{164}$

155 JF Colares and A Rode, 'Working Paper: Climate Change Mitigation and Trade Rules: The Opportunities and Limitations of Neutral Border Tariffs' (Energy Policy Institute at the University of Chicago 2015) <https://epic.uchicago.edu/research/publications/climate-change-mitigation-andtrade-rules-opportunities-and-limitations $>$. Colares and Rode argue that marginally increasing tariffs on foreign production and emissions, as a result of national (or EU) industry lobbying, may increase home production and emissions, which may be particularly harmful in case the latter is carbon-intensive; increased home production may thus decrease global welfare. The authors admit, however, that informational requirements for evaluating [border carbon adjustment] on the grounds of economic efficiency might be administratively and statistically prohibitive' (35).

${ }^{156}$ This would also have to take into account the CBDR principle, discussed below in relation to the chapeau of art XX and returning in the analysis of customary international law in Section V.

157 Brazil-Retreaded Tyres (n 146) [307].

158 EC-Asbestos (n 123) [165]. Nor may a proposed alternative be 'merely theoretical in nature' (Brazil-Retreaded Tyres (n 146) [156].

159 See the IMO media statement on the 2009 meeting of the Marine Environment Protection Committee (MEPC 59): IMO, 'Market Based Measures' (www.imo.org, 2016) < http://www.imo. org/en/OurWork/Environment/PollutionPrevention/AirPollution/Pages/Market-Based-Measures. $\operatorname{aspx}>$.

160 See also Regulation 2015/757 (n 7) rec 10.

161 Korea-Beef (n 146) [162].

162 G Marceau and JP Trachtman, 'A Map of the World Trade Organization Law of Domestic Regulation of Goods: The Technical Barriers to Trade Agreement, the Sanitary and Phytosanitary Measures Agreement, and the General Agreement on Tariffs and Trade' (2014) 48 JWT 351.

163 UNFCCC (n 52) rec 1.

164 Brazil-Retreaded Tyres (n 146) [151]. 


\section{Article XX(g) GATT: 'relating to the conservation of exhaustible natural resources'}

The EU maritime measures may also be exempted under Article XX(g), which captures measures aimed at the conservation of exhaustible natural resources, as long as they 'relate to' that objective and are made effective in conjunction with domestic restrictions. ${ }^{165}$ A leading case here is US-Shrimp, which concerned a US import ban on shrimp and shrimp products from countries that had not used certain turtle-friendly fishing nets. ${ }^{166}$ There, the AB held that 'the term "exhaustible natural resources" must be read [...] in light of contemporary concerns of the community of nations about the protection and conservation of the environment.' ${ }^{167}$ Considering the sustainable development objective embodied in the WTO Agreement, it went on to find that 'the generic term "natural resources" in Article $\mathrm{XX}(\mathrm{g})$ is not "static" in its content or reference but rather "by definition, evolutionary", ${ }^{168}$ Here too, Article XX is thus interpreted flexibly to allow States to respond to emerging scientific evidence on common environmental concerns. Such an approach is not only for the benefit of a single State's regulatory autonomy, it also facilitates the protection of 'higher' shared interests.

In addition, the fact that a resource may be 'renewable' does not mean that it is not 'exhaustible'. ${ }^{169}$ This was confirmed in US-Gasoline (Panel) where the Panel found clean air to be an exhaustible natural resource as it can be depleted by means of pollution from fuel combustion. ${ }^{170}$ It has been argued that by analogy, a 'stable atmosphere' is an exhaustible natural resource, as the necessary composition of gases is also disrupted by $\mathrm{CO}_{2}$ emissions from fuel combustion. ${ }^{171}$ Furthermore, the EU's above-mentioned air quality objective indicates that the envisioned measures would also fall under a narrower reading of the provision.

Under Article XX(g), a measure must also 'relate to' its objective. This pertains to the 'relationship between the general structure and design of the measure' and 'the policy goal it purports to serve'. ${ }^{172}$ What is required is 'a close and genuine relationship of the ends and means', where the rules are not merely 'incidentally or inadvertently' aimed at conservation. ${ }^{173}$ As discussed, the MRV and MBMs would be primarily directed at reducing $\mathrm{CO}_{2}$ emissions in order to mitigate climate change, and are capable of achieving

\footnotetext{
165 Note, assuming a maritime ETS would have the same scope as the MRV, it would also meet the requirement of being 'made effective in conjunction with restrictions on domestic production or consumption', as all intra-EU voyages would also be subject to the scheme.

166 US-Shrimp (n 140) [2].

167 ibid [129] (emphasis added). The AB continues: 'the preamble attached to the WTO Agreement shows that the signatories to that Agreement were, in 1994, fully aware of the importance and legitimacy of environmental protection as a goal of national and international policy'. $\quad 168$ ibid. 169 US-Gasoline (Panel) (n 18) [6.37]. 170 ibid.

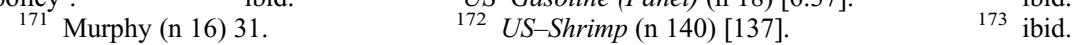


significant reductions. The arguments supporting necessity are sufficient to meet the 'related-to' requirement here.

The above analysis demonstrates that the EU METS and planned MBMs could be provisionally justified under Article XX(b) and (g) GATT, both of which accommodate the protection of common concerns. However, the actual application of these measures must meet the stringent requirements of the chapeau, which will now be discussed in more detail.

\section{Article XX GATT chapeau}

The chapeau of Article XX GATT contains additional obstacles for the application of prescriptive measures provisionally justified under the provision's sub-paragraphs. Such measures must not constitute 'arbitrary or unjustifiable discrimination' or a 'disguised restriction on international trade'. According to the $\mathrm{AB}$ in US-Shrimp, 'the chapeau of Article XX is, in fact, but one expression of the principle of good faith', prohibiting the abuse of rights and requiring States to exercise their rights 'reasonably'. ${ }^{174}$

To avoid 'arbitrary or unjustifiable discrimination', States must make serious best-efforts to reach a multilateral solution, before resorting to unilateral action. ${ }^{175}$ In US-Shrimp (Article 21.5) the AB held that while a multilateral approach would be 'preferred', the actual conclusion of an agreement is not required. ${ }^{176}$ In the present case, EU Member States have been lobbying for the regulation of maritime emissions in the IMO since 2009, submitting various ETS proposals. ${ }^{177}$ By the MEPC68 meeting in May 2015, these repeated efforts had still achieved no results, the Committee deciding once again not to set a quantifiable reduction target for maritime emissions. ${ }^{178}$ Even after issuing the MRV, the EU continues to stress its preference for a multilateral solution, noting that ' $[\mathrm{t}]$ he likely timeline for the Regulation's adoption leaves ample opportunity for the IMO to make progress before the EU rules come into force'. ${ }^{179}$

In US-Shrimp, the $\mathrm{AB}$ further found that a measure will not constitute arbitrary or unjustifiable discrimination in violation of the chapeau of Article

\footnotetext{
174 ibid [158].

175 WTO, United States - Import Prohibition of Certain Shrimp and Shrimp ProductsRecourse to Article 21.5 of the DSU by Malaysia (21 November 2001) WT/DS58/AB/RW [124]. 176 ibid.

177 Separate submissions were made by France: Emissions Trading System (ETS) for International Shipping (France (MEPC 60/4/41); and the United Kingdom: Global Emissions Trading System (ETS) for international shipping (United Kingdom (MEPC 60/4/26). See further IMO, 'Market-Based Measures' (www.imo.org, 2016) < http://www.imo.org/en/OurWork/ Environment/Pages/Default.aspx $>$.

${ }^{178}$ See the IMO media statement on the MEPC 68: IMO, 'Marine Environment Protection Committee (MEPC), 68th Session, 11 to 15 May 2015' (www.imo.org, 15 May 2015) <http:// www.imo.org/en/MediaCentre/MeetingSummaries/MEPC/Pages/MEPC-68th-session.aspx>.

${ }^{179}$ European Commission, 'Time for International Action on $\mathrm{CO}_{2}$ Emissions from Shipping' (www.ec.europa.eu, 2016) <https://ec.europa.eu/clima/sites/clima/files/transport/shipping/docs/ marine_transport_en.pdf>.
} 
$\mathrm{XX}$ if it is sufficiently flexible so as not to effectively require 'all other exporting Members [...] to adopt essentially the same policy'. ${ }^{180}$ The measure must also 'allow for comparably effective third country measures', taking into account 'the specific conditions prevailing in its territory'. ${ }^{181}$ With regard to flexibility, the MRV recognizes four different types of recording methods, allowing operators to choose a system best fitted to, or already present on their ships. The EU plans to accommodate third country conditions through its 'staged approach', in which it first implements the MRV before 'pricing the emissions at a later stage'. ${ }^{182}$ This 'facilitates the making of significant progress at international level', allowing the final market-based measure to be better suited to comparable third country measures. ${ }^{183}$ It remains to be seen whether the EU will include recognition for comparably effective measures in its chosen MBM. If it chooses an ETS, it may follow the approach taken in the Aviation Directive, which allowed for the recognition of third country policies where they adopt 'measures that have an environmental effect at least equivalent to that of this Directive'. ${ }^{184}$

Notably, in the field of climate change, consideration for third country conditions must also take into account the CBDR principle, which requires States to divide the cost of mitigation according to their respective capabilities. ${ }^{185}$ Applied here, this arguably means that where a developing State has, for capacity reasons, chosen to implement less stringent climate protection standards, its measures should not be automatically rejected by the EU. The approach in the Aviation Directive that only recognizes measures with 'equivalent' environmental effect, may thus not take due consideration of the circumstances in the exporting country.

In Brazil-Retreaded Tyres it was further found that any discriminatory effects of the measure must be 'explained by a rationale that bears ... [a] relationship to the objective of a measure'. ${ }^{186}$ Here, the higher costs allotted to operators further away is related to the fact that they travel further and therefore emit more. Finally, it has been suggested that the reasonableness requirement also obliges the EU to take into account and deduct any double taxation should the emissions already be subject to another regime. ${ }^{187}$ This is something that the EU will have to consider when further designing its chosen MBM.

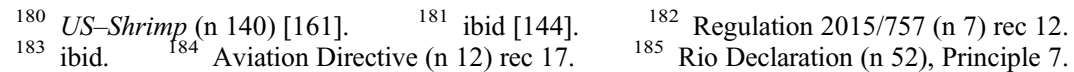

186 Brazil-Retreaded Tyres (n 146) [232]. See also WTO, United States - Measures Concerning The Importation, Marketing and Sale of Tuna and Tuna Products (Recourse to Article 21.5 of the DSU by Mexico) - Report of the Appellate Body (20 November 2015) WT/DS381/AB/RW/Add.1 [95].

77 See C Voigt, 'WTO Law and International Emissions Trading: Is There Potential for Conflict?' (n 140) 62. 


\section{An implied jurisdictional limitation in Article XX GATT?}

The analysis above indicates that the EU maritime measures could provisionally be justified within the WTO framework. However one key issue remains to be considered, namely whether Article XX GATT contains an implied jurisdictional limit that would exclude from its scope measures with an 'extraterritorial element' like those at issue here. Such measures have traditionally been frowned upon under world trade law, although over time the WTO has gradually taken a more permissive stance towards measures serving a recognized public interest. Thus in US-Tuna (1994), the Panel found that the GATT could, in principle, apply to policies 'relating to things or actions outside the territory of the regulating State'. ${ }^{188}$ However, while the Panel found that Article XX(g) could apply to conservation measures for resources outside a State's jurisdiction, ${ }^{189}$ it held that where the measure coerced other States to change their policies within their own jurisdictions, it could never be 'necessary' within the meaning of Article XX(b). ${ }^{190}$

This finding was reversed in US-Shrimp (1998), where the AB held that 'requiring from exporting countries compliance with [...] certain policies' does not render a measure 'a priori incapable of justification under Article XX' ${ }^{191}$ 'Such an interpretation renders most, if not all, of the specific exceptions of Article XX, inutile.' 192 It did, however, require a 'sufficient nexus' between regulating State and the objective pursued by the measure, in order for that State to claim jurisdiction. ${ }^{193}$ There the US needed to prove its connection with migratory sea turtles in order to be eligible for exemption under Article XX $(\mathrm{g})$. The AB found that although the sea turtle species were 'highly migratory animals', the fact that they were known to occur within US territorial waters provided a 'sufficient nexus' between the endangered population and the US. Notably, however, this finding was limited to the specific circumstances of the case and the $\mathrm{AB}$ explicitly declined 'to pass upon the question of whether there is an implied jurisdictional limitation in Article XX(g)'. ${ }^{194}$

To date the question of whether there is an implied jurisdictional limit in Article XX remains unclear. ${ }^{195}$ In line with Article 3.2 DSU, we are left with Articles 31 and 32 of the Vienna Convention on the Law of Treaties (VCLT) for interpretative assistance. Neither the object and purpose (Article 31(1) VCLT) nor the travaux préparatoires (Article 32 VCLT) of the GATT

\footnotetext{
188 United States - Restrictions on Imports of Tuna-Panel Report (16 June 1994) DS29/R (unadopted)) [5.16], [5.20].

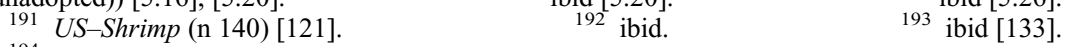

194 ibid.

195 In EC-Seals (n 124) the AB did not explicitly discuss the issue of territorial limits, though it implied that the public morals which were the object of the measure were held by all citizens within the EU's territory. See for further analysis, R Howse, J Langille and K Sykes, 'Sealing the Deal' (2014) 18 ASIL Insights $<$ https://www.asil.org $>$.
} 
provide much clarity on the issue. ${ }^{196}$ It is argued that, based on Article 31(3) (c) VCLT, other 'relevant rules of international law' applicable between the parties should be relied on here. Neither the UNFCCC nor the Kyoto and Paris agreements provide much clarity on the territorial limits of unilateral emission reduction policies. However, as the question pertains to jurisdiction, the most 'relevant' rules are those of customary international law of State jurisdiction. ${ }^{197}$ Unlike MEAs, these rules apply between all WTO members and can also be applied to the non-environmental exemptions of Article XX. ${ }^{198}$ As with the LOSC we are once again directed to customary international law to complete the jurisdictional analysis. Section V examines this in more detail, exploring the customary bases and limitations for State jurisdictional rights to respond to common concerns.

V. PROTECTING COMMON CONCERNS UNDER THE CUSTOMARY INTERNATIONAL LAW OF STATE JURISDICTION

We have seen that there is compelling legal support for the argument that States (and regional organizations) have a duty to respond to common concerns through cooperation and 'other-regardingness' (Section IIB). The latter more specifically includes States' due-diligence obligation to anticipate, prevent and minimize their contribution to common environmental concerns. The above analysis has further shown that legislative measures aimed at doing so are at least accommodated, and arguably supported, by both the LOSC and world trade law (Section IV). Still, a jurisdictional analysis of both regimes is not complete without taking into account customary international law. From a doctrinal perspective, it is this regime that is fundamentally tasked with appropriately delimiting sovereign powers, taking into account both the right to independence and the realities of interdependence. Section VA explores how this balance could be struck in the relatively unchartered territory of common concerns. The overarching jurisdictional limitations are considered in Section VB.

\footnotetext{
196 The travaux préparatoires are in fact the preparatory works of the Charter of the International Trade Organisation (ITO). These do not clarify the issue of territorial limitation as they were focused on the effects of lower trade standards. See further Bartels (n 76) 353; B Cooreman, 'Addressing Environmental Concerns through Trade? A Case for Extraterritoriality' (2015) 65 ICLQ 229. See also S Charnovitz, 'Exploring the Environmental Exceptions in GATT Article XX' (1991) 25 JWT 37.

197 For explicit endorsement of this approach see Bartels (n 76) 360; Cooreman (n 196) 234; Murphy (n 16) 31.

198 For an extensive analysis using MEAs to interpret the GATT see G Marceau, 'A Call for Coherence in International Law: Praises for the Prohibition against "Clinical Isolation" in WTO Dispute Settlement' (1999) 33 JWT 87.
} 


\section{A. Common Concerns and the 'Substantial and Genuine Connection' Requirement}

From a jurisdictional perspective, measures with an 'extraterritorial element' are suspect, as they risk infringing upon the freedom of other equally sovereign States. As we have seen, it is now generally accepted that such measures can be justified where a State or regional organization can demonstrate a 'substantial and genuine connection' to the regulated subject matter. ${ }^{199}$ As one of the founding fathers of this theory, FA Mann defined this requirement as a 'meaningful connection', to be determined by a 'weighing of legally relevant elements' to 'justify, or make it reasonable for, a State to exercise legislative jurisdiction'. ${ }^{200}$ According to Mann, 'merely' an economic, political, commercial, or social interest is not sufficient to support the connection. ${ }^{201}$ Today, this emphasis on the 'legal' nature of the connection seems falsely abstract. As argued by Bartels, where State practice and opinio juris demonstrate that certain interests merit the exercise of jurisdiction, then a customary rule develops to support this. ${ }^{202}$ Essentially, this test for a lawful exercise of jurisdiction entails a balance of interests to determine, in a specific case, whether one State's interest can legitimize limiting the legislative freedom of another State. ${ }^{203}$

How then must one go about demonstrating such a 'substantial and genuine connection'? Traditionally this is done using the five prescriptive bases of territory, nationality, protection, effects and universality discussed in Section IIC. ${ }^{204}$ However, as noted by Kamminga, the traditional bases 'do not provide a coherent and straightforward model' to authoritatively determine the legality of an exercise of prescriptive jurisdiction. ${ }^{205}$ While well recognized in theory, the fragmented State practice provides limited support in the relatively new field of common environmental concerns. For this reason, while the following section channels the analysis through the

\footnotetext{
199 See eg R Jennings and A Watts, Oppenheim 's International Law (9th edn, OUP 1992) 456-8; J Crawford, Brownlie's Principles of Public International Law (8th edn, OUP 2012) 447; FA Mann, 'The Doctrine of Jurisdiction in International Law' (1964) 111 RdC 9; Kamminga (n 61) [9]; and A Bianchi, 'Current Trends in Legal Scholarship: the Alleged Antinomy between Traditional Notions of the International Law of Jurisdiction and Recent Methods of Interest Analysis' in KM Meessen (ed), Extraterritorial Jurisdiction in Theory and Practice (Kluwer Law International 1996) 83-4.

${ }^{200}$ FA Mann, 'The Doctrine of International Jurisdiction Revisited after Twenty Years' (1984) $186 \mathrm{RdC} 28$.

201 Mann (n 199) 28.

202 Bartels (n 76) 372. See also Bianchi who requires an 'effective and significant connection between the regulating state and the activity or fact to be regulated', to be determined based precisely by state practice. (A Bianchi, 'Jurisdictional Rules in Customary International Law' in Meessen (n 199) 90-1).

203 See Crawford, Brownlie's Principles of Public International Law (n 199) 456-7.

204 These function, more as a matter of convenience than of substance to evidence a substantial and genuine connection. Jennings and Watts (n 70) 456-8.

${ }^{205}$ Kamminga (n 61) [16]. See also D Svantesson, 'A New Jurisprudential Framework for Jurisdiction: Beyond the Harvard Draft’ (2015) 109 AJIL Unbound 69, 70-1.
} 
traditional bases, it seeks to combine their Westphalian origins with the realities of common environmental concerns.

As we have seen in the $A T A A$ case, on one view, physical presence, such as that of vessels in EU ports, provides 'unlimited jurisdiction' based on the territoriality principle. ${ }^{206}$ However, as already noted, this appears to blur the conceptual distinction between prescriptive and enforcement jurisdiction (Section IIC). It also effectively allows all import and export measures an unlimited territorial scope. This approach thus permits powerful States to exercise unbridled market power, threatening the sovereign independence its proponents claim to protect. Finally, the international reaction to the CJEU's use of this reasoning illustrates that this is not a politically tenable interpretation of the substantial connection requirement. We therefore argue that States must do more than simply demonstrate a formal territorial connection to justify market entry conditions that take into account conduct abroad. While presence may be a sufficient trigger to justify enforcement, the threshold for demonstrating a legitimate interest in legislating is higher.

The nationality principle is of little help here, as the EU measures also cover non-EU flagged vessels. The protective principle, allowing for regulation of activities threatening a vital national interest, could conceivably cover action causing grave environmental harm. ${ }^{207}$ However, this is difficult to apply to situations with such diffuse causality as climate change, and the threshold for what constitutes a 'threat' is furthermore a high one. ${ }^{208}$

We therefore turn to effects-doctrine, which provides a basis for jurisdiction over conduct by foreign nationals occurring outside of its territory where it has a 'substantial effect' within its territory. ${ }^{209}$ The validity and scope of the effectsdoctrine is controversial, however. While some view it as an extension of the objective territoriality principle, it is well accepted in the United States as an independent basis of jurisdiction, ${ }^{210}$ and can be found in section 403(2) of the Third Restatement of the Foreign Relations Law of the United States (US Third Restatement). ${ }^{211}$

Accepting that effects could provide a ground for jurisdiction, we arrive at the threshold issues of the requisite causal link and the scale of the effects. Turning first to causality, some argue that the effects-doctrine should be interpreted strictly, and focus, like the traditional principle of harm prevention, on delineated damage with a direct causal link to another actor. According to

206 Scott (n 71) 87; ATAA Case (n 14) [124]-[125].

207 There is no limited list or set of criteria to determine what constitutes a 'vital' national interest; Crawford, Brownlie's Principles of Public International Law (n 199) 462.

208 Ringbom (n 11) 631. 2092006 ILC Report on Extraterritorial Jurisdiction (n 60) 522.

210 This is especially true for anti-trust law. See further C Ryngaert, Jurisdiction over Antitrust Violations in International Law (Intersentia 2008).

211 US 3rd Restatement (n 64) section 403(2). See Hertogen (n 46) 924, for an interesting conceptualization of 'locality of effects' as a basis for prescriptive jurisdiction allowing States to discharge their sovereign responsibilities which are effected by the negative externalities of foreign conduct. 
this view, the EU must be able to identify 'a specific environmental outcome' in its territory caused by GHG emissions from ships. ${ }^{212}$ However, this focus on specific, direct harm does not fully comprehend the complex processes involved in climate change. The fact that cause (maritime and emissions) and effect (climate change) cannot be isolated to one specific environmental outcome does not mean that there is no causality. ${ }^{213}$

A broader take on the effects-doctrine recognizes the indirect effects felt globally using a process-based understanding of anthropogenic interference with the climate system. As discussed, $\mathrm{CO}_{2}$ emissions cause an imbalance in the atmospheric concentration of greenhouse gases that leads to climate change. In turn, climate change leads to the destruction of ecosystems, extreme weather and other environmental harm occurring in all States, including the EU. ${ }^{214}$ Exploring this issue in the field of State responsibility, Peel considers that GHG emitted by a State could constitute the 'proximate cause' of environmental injury (effects), where it makes a 'meaningful or material contribution to the risk of climate change harm'. ${ }^{215}$ On one view, each cumulative tonne of GHG makes a 'material contribution' to the risk. Yet in the context of responsibility this would resemble a strict liability test, 'at odds' with the primary due-diligence obligations in the field of climate change. An alternative approach based on the precautionary principle is thus preferred. ${ }^{216}$ Notably, in the context of jurisdiction, causality serves to demonstrate an interest in legislating to mitigate harm, rather than the liability of another State for causing harm. This supports rather than conflicts with States' due-diligence obligations. The 'material contribution' threshold is then better framed in terms of degree, where the activity regulated must either immediately or over time make an objectively provable contribution to the harm. Scientific and economic evidence is particularly helpful in this respect. ${ }^{217}$

\footnotetext{
${ }^{212}$ See in particular Hermeling et al. (n 16) 15 , who argue that '[d]ue to the high complexity of the climate change process, a chain of causes and effects that would clearly link GHG emissions from vessels anywhere in the world with specific environmental outcome, can scarcely be identified'.

213 Bäuerle et al. (n 16) 3.

214 See further on the causality between conduct and effects, C Voigt, 'Up in the Air - Aviation, the EU Emissions Trading Scheme and the Question of Jurisdiction' in C Barnard (ed), Cambridge Yearbook of European Legal Studies (Hart Publishing 2012). See also F Biermann, 'The Rising Tide of Green Unilateralism in World Trade Law. Options for Reconciling the Emerging North-South Conflict' (2001) 35 JWT 421, 431.

${ }^{215}$ Peel (n 53) 28. Peel refers to support from domestic practice, including: Clements v Clements 2012 SCC 32, [2012] 2 SCR 181, para 43; Fairchild v Glenhaven Funeral Services Ltd., [2002] UKHL 22, [2002] 3 All ER 305; and Barker v Corus UK Ltd., [2006] UKHL 20, [2006] 2 AC. She notes, however, that this is insufficient to support a general principle of international law.

${ }^{216}$ In support of this threshold, Peel refers here to Voigt (n 55) 16, citing Southern Bluefin Tuna Cases (New Zealand v Japan; Australia v Japan), (Provisional Measures) ITLOS Case No 3 and 4, (27 August 1999) ITLOS Rep 1999, 280.

${ }^{217}$ For a consideration of climate change loss and damage see eg K Pinninti, Climate Change Loss and Damage (Springer 2014).
} 
The next threshold issue for effects-based jurisdiction is the scale of the effects themselves. It seems a logical starting point that the greater the effects, the greater a State's claim to a genuine connection. When considered from the perspective of a single State this is hardly controversial, and indeed appears reflected in the requirement of 'direct and substantial effects' well rooted in both US and EU antitrust law. ${ }^{218}$ While there remains little legal clarity on what this means in practice, ${ }^{219}$ one could safely assume that the irreversible environmental harm caused by climate change would meet this threshold. This arguably applies more generally to all common concerns, which by definition have been recognized by the international community to be grave enough to require action. Accepting this reasoning, based on the territorial effects alone, the EU arguably has a sufficient nexus to regulate global maritime emissions and enforce this regulation in its ports. ${ }^{220}$

However, the analysis of effects-based jurisdiction for common concerns does not end here. It is further submitted that the gravity of the effects should not only be measured in terms of local intensity, but also in terms of total territorial scope. Thus, where a State is legislating to mitigate harmful effects felt globally, this should lend weight to its claim to a 'substantial and genuine connection' to the subject matter. This is a way of representing the interests of the broader international community using the State-centric tools of the law of jurisdiction. ${ }^{221}$ Indeed, from both a practical and normative perspective it is necessary to consider the legitimate interests of other effected actors, rather than artificially limiting the analysis to the acting State. ${ }^{222}$ Support for this can be found in the section 403(2) of the US Third Restatement, which provides that States must consider, inter alia, the importance of the regulation to the international political, legal, or economic system and the regulation's consistency with the traditions of the international system. Fundamentally, this approach accommodates the jurisdictional rights

218 See eg in the US, Mannington Mills, Inc. v Congoleum Corp., 595 F.2d 1287 (3d Cir. 1979); and the Foreign Trade Antitrust Improvements Act of 1982, 15 USC section 6a (FTAIA.); in the EU Case T-102/96 Gencor Ltd v Commission, [1999] ECR II-753.

219 For an analysis of the 'direct' or 'immediate and substantial' effects threshold in antitrust law see Ryngaert (n 210) 59. Hertogen (n 46) 923 argues that there should not be a de minimis 'quantity' of effects required to establish jurisdiction, 'as sovereign states should be able to decide whether the effects they are exposed to, however small, warrant a response'.

220 For support of this view see Bäuerle et al. (n 16) 85; Murphy (n 16) 19.

221 This approach therefore serves to help effectuate the protection of recognized community interests in international law which, as pointed out by Villalpando, continues to be 'pursued through legal tools that were not, at their origins, elaborated for that purpose. See S Villalpando, 'The Legal Dimension of the International Community: How Community Interests Are Protected in International Law' (2010) 21 EJIL 387, 410.

${ }^{222}$ See Cottier et al. (n 22) 5 who argue that common concerns may form the 'normative foundation and limits' for unilateral acts with extraterritorial effects, but stress that such acts must still be 'within the bounds of international law'. Kopela (n 106) 110 argues that '[t]he principle of common concern mitigates the unilateral aspect of such measures by focusing on their objective and benefits'. 
necessary for States to fulfil their obligations to respond to common concerns, improving the coherence between different legal regimes.

The consideration of community interests as a prescriptive basis is not alien to the law of jurisdiction. Indeed, it is the very rationale underlying the universality principle, which provides for jurisdiction with respect to certain grave crimes under international law, without any link or nexus to the legislating State..$^{223}$ There, the intrinsic gravity of the crime gives all States an interest in legislating. 224

It could be argued that this interpretation of the effects-doctrine is problematic, as it constitutes a carte blanche for all States to prescribe far-reaching measures in response to common concerns. This risk should not, however, be overstated. Firstly, while global effects certainly bolster a State's claim to a reasonable interest, they are not necessarily determinative. Other factors such as the strength of a formal 'territorial connection' and the gravity of the territorial harm will also play a role. Causality also poses an important limitation, as the subject matter regulated must make a real contribution to the local and global harm. The measure in question must also be capable of mitigating the harm caused. In the present case, maritime emissions materially contribute to climate change, and the MRV and envisioned MBMs are capable of reducing them. Finally, the concrete exercise of jurisdiction must also comply with the jurisdictional 'reasonableness' limitations discussed in Section VB below.

From a more positivist perspective, explicit consideration of these jurisdictional questions will help to increase clarity on the way in which international law treats acts aimed at protecting common concerns. This could occur within a variety of fora including the WTO, International Tribunal for the Law of the Sea (ITLOS), the CJEU, and even the ICJ. ${ }^{225}$ In this way, unilateral action, such as that of the EU, serves to further the development of international law. ${ }^{226}$

\section{B. Jurisdictional Limitations}

The concrete exercise of jurisdiction must also meet the reasonableness criteria of good faith, proportionality and non-discrimination. ${ }^{227}$ It is submitted that in

223 See further 2006 ILC Report on Extraterritorial Jurisdiction (n 60) [522]; Kamminga (n 61) [14]; L Reydams, The Rise and Fall of Universal Jurisdiction KU Leuven Working Paper No 36 (2010) 7 .

224 See further Ryngaert (n 20) 126; O'Keefe (n 68) 745.

225 For further discussion on the international judicial function in relation to recognized values see P Sands, “'Unilateralism”, Values, and International Law' (2000) 11 EJIL 291, 300.

226 See for normative discussion, D Bodansky, 'What's so Bad about Unilateral Action to Protect the Environment?' (2000) 11 EJIL 339; Hartmann (n 11); Sands (n 225) 300-2.

227 The precise nature of 'reasonableness' as a limitation to the exercise of jurisdiction is a contested topic, which goes beyond the scope of the present contribution. This section limits itself to three generally accepted limitations to State action more generally. See further on reasonableness eg AF Lowenfeld, 'Sovereignty, Jurisdiction, and Reasonableness: A Reply to 
the context of common concerns, the good faith requirement entails that a State has made best-effort attempts to reach a multilateral solution. This is in line with the duty to cooperate in response to common concerns discussed above in Section II. It is also reflected world trade law in the chapeau of Article XX GATT, and in Articles 118 and 300 LOSC. ${ }^{228}$ As discussed, the EU has met this condition.

The proportionality principle directs us to consider the jurisdictional assertion's level of intrusiveness. Firstly, the design of the MRV and planned MBMs focusses on reducing the greatest amount of emissions at the lowest cost to operators, the Commission noting that '[s]hips above 5000 GT account for around 55 per cent of the number of ships calling into Union ports and represent around 90 per cent of the related emissions'. ${ }^{229}$ With regards to the EU MRV, it should be noted that the burden posed on operators is largely administrative, as most ships have already been fitted with the monitoring technology, as well as the possibility of offsets by fuel savings. The MBMs are obviously somewhat more intrusive, with additional costs arising from the obligatory fund contributions, purchase of additional carbon credits, and investment in new technology by operators. The latter, which the measures are intended to incentivize, would however also provide the company with fuel-saving offsets. The investment costs are further limited as much of the technology already exists, the MBMs being aimed at removing the market barriers to their actual use. ${ }^{230}$ As such, the Commission's impact assessment predicts a possible negative total cost in the mid-to-long term. ${ }^{231}$

Under the proportionality principle, not only the impact on private economic operators but also on other States must be taken into account. Thus, a measure must not unduly limit the legislative freedom of other States to apply their own comparable measures. ${ }^{232}$ This is also visible in the discussion on unjustifiable discrimination of the chapeau of Article XX GATT (see Section IVB). In the context of climate change, the proportionality requirement also reinforces the duty to act in accordance with the CBDR principle. ${ }^{233}$ This means that the final MBM will require a mechanism for recognition and integration of comparable third State measures, with consideration of the differing capacities of the participating States.

A. V. Lowe' (1981) 75 AJIL 629; HG Maier, 'Interest Balancing and Extraterritorial Jurisdiction' (1983) 31 AmJCompL 579; C Ryngaert (n 20) ch V.

228 See also North Sea Continental Shelf (Germany v Denmark) (Merits) [1969] ICJ Rep 3, 97.

229 See Regulation 2015/757 (n 7) rec 9: 'According to data provided by the IMO, the specific energy consumption and $\mathrm{CO}_{2}$ emissions of ships could be reduced by up to $75 \%$ by applying operational measures and implementing existing technologies; a significant part of those measures can be regarded as cost-effective and being such that they could offer net benefits to the sector, as the reduced fuel costs ensure the pay-back of any operational or investment costs.'

230 Executive Summary of the MRV Impact Assessment (n 84) 2.

232 Bäuerle et al. (n 16) 86.

233 See for further analysis of CBDR and EU climate policy, J Scott and L Rajamani, 'EU Climate Change Unilateralism' (2012) 23 EJIL 469. 
As regards the non-discrimination requirement, we have seen that the MBMs may pose a heavier burden on ships travelling from further away. However, as the EU's measures address all ship operators irrespective of their flag, and all voyages irrespective of the port of origin, it is difficult to maintain that they discriminate between operators. ${ }^{234}$ In any event, the differentiation based on origin is directly related to the objective of reducing emissions, and its absence would greatly diminish the measures' effectiveness. We therefore conclude that the EU's measures, if applied proportionately, are permitted by the customary law of jurisdiction.

\section{CONCLUSION}

By taking provocative climate action the EU has proved willing to extend its environmental legislation beyond its own borders. The recently adopted Regulation $2015 / 757$ is a key example, incorporating 'extraterritorial' emissions, including those of foreign operators. The Regulation is intended as a precursor to a market-based measure (MBM), echoing the earlier adopted-though temporarily doomed-Aviation Directive. In international law, unilateral measures with such 'extraterritorial elements' are jurisdictionally suspect, as they may be seen to trample on the territorial prerogatives of other sovereigns. This raises particular tensions when such measures are taken in response to internationally recognized 'common concerns' like climate change. In such situations, we are confronted with a conflict of paradigms between the interdependence-focussed common concern obligations and the independence-focussed jurisdictional rights.

Our analysis has demonstrated, however, that these two paradigms need not be incompatible. The Law of the Sea Convention (LOSC) does not pose clearcut territorial limits to port and coastal States' (and the EU's) regulatory competences. At the same time, the law of the World Trade Organization (WTO) allows States and the EU to justify non-neutral trade restrictions furthering global environmental aims, as long as some territorial connection can be established. Ultimately, however, the LOSC and WTO law remain overly vague regarding the connection which international law requires between the regulating State (or the EU) and the subject matter at issue. We have therefore devoted special attention to the customary law of state jurisdiction supplementing these regimes. We have posited that, while the law of jurisdiction demands a substantial connection for an assertion to be presumptively lawful, such a connection should be construed in light of common concerns, which by their very nature have diffuse territorial effects in all States. It is the combination of climate change's indirect effects on the territory of EU, and the nature of the climate change problématique as a

234 Regulation 2015/757 (n 7) rec 14. 
common concern, which serves as the legal basis for the EU's climate change unilateralism, more specifically for the MRV and the envisaged MBM.

Outstanding issues for the institutional design of unilateral measures pertain to their application to developing countries in light of the principle of common but differentiated responsibilities, as well as, somewhat relatedly, to the global welfare maximization potential of unilateral measures. This calls for vigilance in determining the precise design of climate-protective unilateral trade measures. However, given that the best option of adequate multilateral measures has not materialized, carefully crafted unilateral measures remain a defensible second-best option for addressing global climate change. 